\title{
Constitutive and Induced Salt Tolerance Mechanisms and Potential Uses of Limonium Mill. Species
}

\author{
Sara González-Orenga ${ }^{1,2}$, Marius-Nicusor Grigore ${ }^{3}$, Monica Boscaiu ${ }^{1, *}$ and Oscar Vicente ${ }^{2}$ (D) \\ 1 Mediterranean Agroforestry Institute, Universitat Politècnica de València, Camino de Vera $\mathrm{s} / \mathrm{n}$, \\ 46022 Valencia, Spain; sagonor@doctor.upv.es \\ 2 Institute for Conservation and Improvement of Valencian Agrodiversity, Universitat Politècnica de València, \\ Camino de Vera s/n, 46022 Valencia, Spain; ovicente@upvnet.upv.es \\ 3 Doctoral School of Faculty of Biology, Alexandru Ioan Cuza University of Iasi Romania, Bulevardul Carol I, \\ Nr.11, 700506 Iaşi, Romania; nicusor.grigore@uaic.ro \\ * Correspondence: mobosnea@eaf.upv.es
}

Citation: González-Orenga, S.; Grigore, M.-N.; Boscaiu, M.; Vicente, O. Constitutive and Induced Salt Tolerance Mechanisms and Potential Uses of Limonium Mill. Species. Agronomy 2021, 11, 413. https:// doi.org/10.3390/agronomy11030413

Academic Editor: Bronwyn Barkla

Received: 8 February 2021

Accepted: 21 February 2021

Published: 24 February 2021

Publisher's Note: MDPI stays neutral with regard to jurisdictional claims in published maps and institutional affiliations.

Copyright: (C) 2021 by the authors Licensee MDPI, Basel, Switzerland. This article is an open access article distributed under the terms and conditions of the Creative Commons Attribution (CC BY) license (https:// creativecommons.org/licenses/by/ $4.0 /)$

\begin{abstract}
Limonium is one of the most interesting and biodiverse genera of halophytes, with many species adapted to saline environments. Limonium species have a promising potential as cultivated minor crops as many have ornamental value, or are already used as medicinal plants. Other species are marketed as gourmet food or can be used for decontamination of polluted soils. Design and implementation of specific breeding programmes are needed to fully realise this potential, based on the vast genetic variation and high stress tolerance of wild species within the genus. Most Limonium species are halophytes, but many are also resistant to drought, especially those from the Mediterranean and other arid regions. Such species constitute attractive models for basic research on the mechanisms of stress tolerance, both constitutive and induced. As typical recretohalopyhtes, with excretive salt glands, Limonium species possess remarkable morpho-anatomical traits. Salt tolerance in this genus relies also on ion accumulation in the leaves, the concomitant use of diverse osmolytes for osmotic adjustment, and the activation of efficient antioxidant systems.
\end{abstract}

Keywords: halophytes; ornamental; recretohalophytes; osmolytes; antioxidants

\section{Introduction}

The genus Limonium is the most biodiverse within the Plumbaginaceae family, distributed throughout the world. The number of its species was estimated to be around 400 [1], but including the numerous microspecies recently described, endemic to small territories, the total number can reach ca. 600 species [2]. In the Mediterranean region, Limonium is extremely rich in endemic taxa, with $70 \%$ of the total number of species endemic [2]; it is the richest genus in endemic species in the vascular floras of Italy, Spain, and Greece [3]. The genus includes many threatened taxa; 159 species are catalogued worldwide in red lists, red books, or lists of protected species at the national and regional levels [4]. However, the highest concentration of endemic and threatened species is found mainly in the Mediterranean coastal regions [5]. Many of these species grow in plant communities that in Europe fall within Directive 92/43 EEC as priority habitats ChritmoLimonietalia '1240 Vegetated sea cliffs of the Mediterranean coasts with endemic Limonium' and to Limonietalia '1510 Mediterranean salt steppes' [6]. The former habitats are specific saline environments, where only highly specialised halophytes can thrive, whereas the latter are found along the Mediterranean coastline and on the edges of the inland marshlands [7]. The exceptional biodiversity within this genus is related to the combination of sexual reproduction with apomixis, and a high frequency of polyploidisation, hybridisation and introgression [8,9]. Due to its complex diversity, Limonium has been the subject of many taxonomical studies, starting with the first infrageneric classification by Boissier $[10,11]$ to molecular phylogenetic analyses during the last two decades $[2,9,12-14]$. 
Limonium species are mostly C3 perennial herbs or shrubs, with rosulate leaves and ascendant floral scapes, simple or ramified with abundant spikelets of small flowers grouped in panicles, which make them attractive as ornamentals. Limonium species are found on sandy beaches, cliffs, and salt marshes in coastal areas, but also in continental areas in lagoons, meadows, steppes, and deserts [2].

Species of this genus were regarded as facultative halophytes, as many have an optimal growth in the absence of salinity but appear in nature only on saline soils, mostly due to poor competition with other plant species in non-saline habitats [15]. Still, many Limonium species tolerate high saline concentrations and behave as true halophytes, with optimal growth under moderate salinity [16,17], and almost all are exclusive to saline habitats.

Limonium belongs to a specific category of halophytes, the so-called 'recretohalophytes', which includes around 370 species [18], able to secrete salt from their leaves through salt bladders and salt glands. Salt bladders consist of single epidermal cells or modified trichomes that accumulate salt on the leaf surface; salt glands, on the other hand, are stable structures formed by two or more cells, often sunken into the epidermis, that continuously secrete toxic ions to the outside of the plant [18-20]. The salt glands are specific to several genera (including Limonium) of a few families, such as Plumbaginaceae, Acanthaceae, Tamaricaceae, Frankeniaceae, Amaranthaceae or Gramineae [21]. Salt glands play an essential role in maintaining the ion balance, contributing to the stability of osmotic pressure and enhancing salinity tolerance [22,23]. Salt glands also act regulating the internal ionic composition of the leaves, which, together with efficient osmotic adjustments, help avoid dehydration of leaf cells [19]. One of the main mechanisms ensuring osmotic balance under stress is the synthesis and accumulation in the cytoplasm of compatible solutes, the so-called osmolytes. These are diverse organic compounds that, apart from their fundamental function in osmotic adjustment, play additional roles in stress tolerance mechanisms; for example, increasing the thermodynamic stability of folded proteins and directly protecting macromolecular structures-in their role as low-molecular-weight chaperons-and also as scavengers of 'reactive oxygen species' (ROS), or as signalling molecules [24-28]. However, osmolyte biosynthesis represents a high cost for the plants since the same cellular osmolarity can be reached by ion uptake and transport with much lower energy consumption $[29,30]$. In dicotyledonous halophytes, osmotic adjustment can be provided at lower costs by ion uptake and accumulation, especially $\mathrm{Na}^{+}$and $\mathrm{Cl}^{-}$, which are sequestered in the vacuoles to avoid toxicity effects in the cytosol [31-33].

Salinity, as well as other stressful environmental conditions, increases the production of reactive oxygen species (ROS), triggering oxidative stress and the activation of antioxidant mechanisms $[34,35]$. The most common antioxidant metabolites include phenolic compounds (especially the subgroup of flavonoids), ascorbic acid, glutathione and carotenoids. Catalase (CAT), superoxide dismutase (SOD), ascorbate peroxidase (APX) (and other peroxidases), or redox regulatory enzymes such as glutathione reductase (GR), are some the most relevant antioxidant enzymatic systems activated in plants to respond to deleterious oxidative stress effects [34,36].

The limits of plants' salt tolerance depend on their developmental stages, and younger plants are generally more susceptible to stress [37]. Seed germination and seedling establishment represent the bottleneck of their life cycle, and even in halophytes germination is usually taking place when soil salinity is alleviated [38,39].

In this paper, we review the main mechanisms of salt tolerance reported in different species of the genus Limonium, during seed germination and in adult plants, including responses based on anatomical adaptations, the regulation of ion uptake and transport, osmolyte biosynthesis and metabolic pathways, and the activation of antioxidant mechanisms. The wide range of salt stress responses described in Limonium species makes this genus an attractive model for basic studies on salt tolerance mechanisms. We also mention, briefly, potential uses of Limonium taxa for the development of (minor) food, medicinal and ornamental crops for a sustainable, 'saline' agriculture. 


\section{Limonium, an Infra-Utilised Reservoir of Species with Great Potential as New, Non-Conventional Crops}

Halophytes represent a sustainable alternative to conventional crops in arid and salinised areas, as they are well adapted to saline wetlands and arid soils. As marginal lands are already increasing due to global warming, more practical uses of halophytes are sought. Such species represent a valuable resource in landscape engineering, with a potential role in desalination and erosion prevention or commercial uses as ornamental plants [40,41]. Halophytes also constitute a group of plants of particular interest as a source of nutraceuticals and functional foods; these salt-tolerant species generally possess robust antioxidant defence systems, based on enzymatic activities and non-enzymatic antioxidant compounds, which allow them the reduction of the oxidative stress associated with salinity $[42,43]$. Some secondary metabolites present in halophytes, including carotenoids, terpenes, essential oils and phenolic compounds, may delay the oxidative stress harmful effects, facilitating repairing of tissue injuries and thus prevention of cell death [44].

Limonium includes numerous ornamental species, well known mostly in the cut-flower markets. Plants of this genus have great potential as ornamentals as the coloured calyces remain open after the flowers have senesced. As such, flowers can be used for both fresh and dry arrangements, which can be maintained for long periods. Limonium sinuatum (L.) Mill., L. latifolium (Sm.) Kuntze, L. perezii (Stapf) F.T. Hubb. and L. gemelinii (Willd.) Kuntze are only a few of the well-known cultivated species, known as 'statice' or 'sea lavender'; many additional hybrids and varieties, the product of breeding programmes, also belong to this genus. Recently, there is a growing interest in incorporating traits from less known wild species into new cultivars, as many inhabit marginal lands and are, therefore, more adapted to environmental stress and can grow with a low input of fertilisers and pesticides [45]. Moreover, these wild species represent a vast genetic variation, not yet exploited; crossing different species within this genus is not complicated, and they can also be easily manipulated in vitro $[46,47]$.

Many Limonium taxa have been reported to have medicinal properties [48-50], such as anti-inflammatory [51], antibacterial [52], and antiviral [53] activities. Many species contain efficient free radical scavenging compounds [54-58] and are a promising source of drugs and nutraceuticals for the pharmaceutical and food industries. Trabelsi et al. [56] isolated powerful antioxidant flavonoids from Limonium densiflorum (Guss.) Kuntze, effective against colon carcinoma cell lines and with a significant anti-inflammatory activity in macrophages. Limonium quesadense Erben extracts also exhibited an intense antioxidant activity [59], and infusions and decoctions of L. algarvense Erben flowers showed better antioxidant and anti-inflammatory properties than green tea [60].

Although Limonium is less known than other halophytes as gourmet food on European markets, some species have been reported as possessing a high nutritional value. For example, L. tetragonum (Thunb.) Bullock is appreciated in Korea for its salty taste and was recommended as a suitable vegetable in diets for weight reduction and obesity-related health problems [61]. Limonium vulgare Mill., from a dry area in Tunisia, was found to be an excellent antioxidant edible plant that could be consumed as food complement [62]. Some Limonium species have been proposed as fodder, such as L. stocksii (Boiss.) Kuntze from Pakistan [63] or L. pruinosum (L.) Chaz. from Egypt [64].

Finally, Limonium species are also potential candidates for phytoremediation programmes. Halophytes are expected to respond better than glycophytes in decontamination of polluted soils. They are ideal candidates for phytoextraction, or phytostabilisation of heavy metal-contaminated soils, especially those affected by salinity [65-69]. Recrerohalophytes are of particular interest, as they may remove not only the excess of salt ions but also other toxic elements such as cadmium, zinc, lead, or copper, through the process called 'phytoexcretion' [65]. Among Limonium species, L. carthaginense (Rouy) C.E. Hubb. \& Sandwith proved to be tolerant to trace element contamination [70], and L. sinuatum is a good candidate for lead and cadmium decontamination [71]. 


\section{Morpho-Anatomical Adaptations in Limonium Species}

The morphology and anatomy of vegetative organs in Limonium species are generally well known and have been recently reviewed [23,72]. Studies on Limonium's biology have been mostly linked to the presence of salt glands ('Mettenius' or 'Licopoli' glands/ organs-see [73]), located on the stem and especially on the leaf surface. In fact, there are also some anatomical features found in Limonium that attest the xeromorphic nature of these halophytic species. Overall, taking into account the saline and arid environments where Limonium species grow, they could be considered a special case of xerophytes. This genus could serve as a model for this kind of morphological and anatomical studies [74].

Description of the morphology of the underground organs of Limonium in the botanical literature is sometimes confusing and contradictory. Although Limonium species are clearly recognised and described as perennial species (thus, the plants must possess rhizomes), there is no mention of this modified underground stem in the Romanian flora. Instead, the species are characterised as having 'tap, thick roots' (L. gmelinii), 'thick, with nodes' (L. vulgare Mill.), 'cylindrical root, unbranched or rarely branched in its upper part' (L. latifolium), or 'tap root more or less thick' (L. caspia Willd.) [75]. The same is true for Flora of the USSR, where there is no data about the rhizome, and the underground system is referred to as 'taproot', with a single exception in the case of L. otolepis (Schrenk) Kuntze, which has a 'taproot (or rootstock) fairly stout' [76]. The species L. brasiliense (Boiss.) Kuntze represents another example of this error in terming the rhizome as a root (see discussions in [77]).

Nevertheless, the anatomical investigation of underground organs clarifies this confusion, as the microscopic structure reveals the typical configuration of a stem (rhizome) or a root [78]. In any case, even with available anatomical data on the structure of underground organs in different Limonium species, comparisons and extrapolations must be carried out with caution. Sometimes, the anatomical description of the rhizome and the root can be accurate for a particular species; however, this does not necessarily provide information on the organs' morphology, unless it is clearly specified at which level the cross-sections were performed within an organ. Thus, an organ can be morphologically and anatomically identified as a root or a rhizome for a Limonium species but, in the absence of anatomical data, these results may not be morphologically applicable to other Limonium species. Some research papers contain anatomical information on the main root, lateral roots and rhizome, for example in Limonium gmelinii [79]; in this case, the rhizome is defined as 'the underground part located between the collet and the rosette of leaves that forms in its terminal side, on soil surface'. For this reason, in the absence of precise anatomical data regarding underground organs, in ecophysiological studies on Limonium, it is highly recommended to use the term 'underground system' or 'rhizomatous root system' [17].

A common anatomical feature for the underground organs (rhizome, root) of Limonium species is the extensive development of sclerenchyma tissue [78-81]. This feature has been evidenced in several Mediterranean Limonium species [74]. In the rhizome of Limonium furfuraceum Kuntze, there is a sinuous ring of sclerenchymatous fibres that surrounds the central cylinder, thus acting as a pericycle (Figure 1a); a similar sclerenchymatous ring occurs in the case of the aerial (flowering) stem (data not shown).

In the central cylinder of the L. girardianum (Guss.) Fourr. root, at its periphery, there is a discontinuous mechanical ring, consisting of several convex arches of sclerenchymatous fibres (Figure 1b).

The central cylinder in the rhizome of L. girardianum (Figure 2a) presents at its periphery a thin ring of sclerenchyma, consisting of cords of periphloemic fibres of vascular bundles; the secondary xylem forms a very thick ring, with a large amount of libriform, and many vessels scattered in the interior. In L. girardianum, the central cylinder of the aerial (flowering) stem has at its exterior an extremely thick ring of sclerenchyma fibres, with very thick and intensely lignified walls (Figure $2 b$ ). A similar situation is found in the aerial stem of L. narbonense Mill. (Figure 2c) and L. gmelinii subsp. hungaricum (Klokov) Soó [82]. 


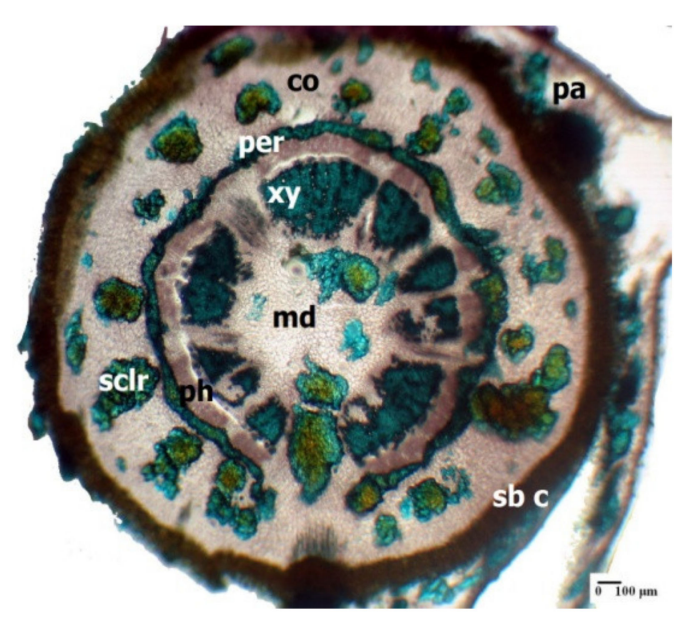

(a)

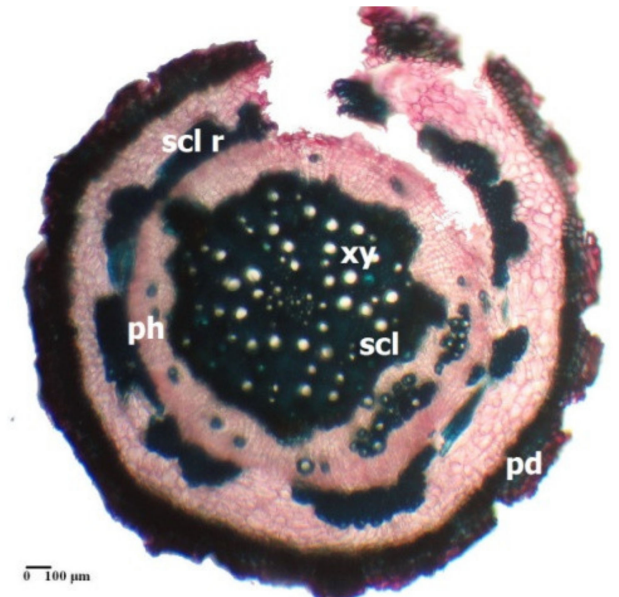

(b)

Figure 1. Cross-section through the rhizome of Limonium furfuraceum (a) and through the root of Limonium girardianum (b); co-cortex; md-medulla; pa-parenchyma; per-pericycle; ph—phloem; xy—xylem vessel; sb c—suberified cells; pd-periderm; scl r—sclerenchyma ring; scl—sclerenchyma; sclr-sclereid.

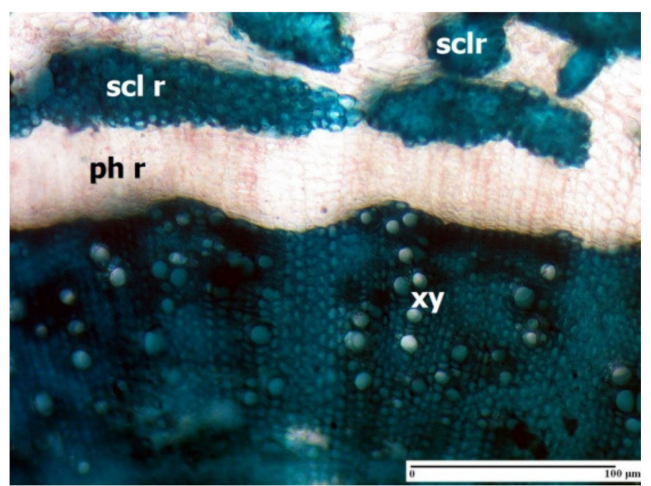

(a)

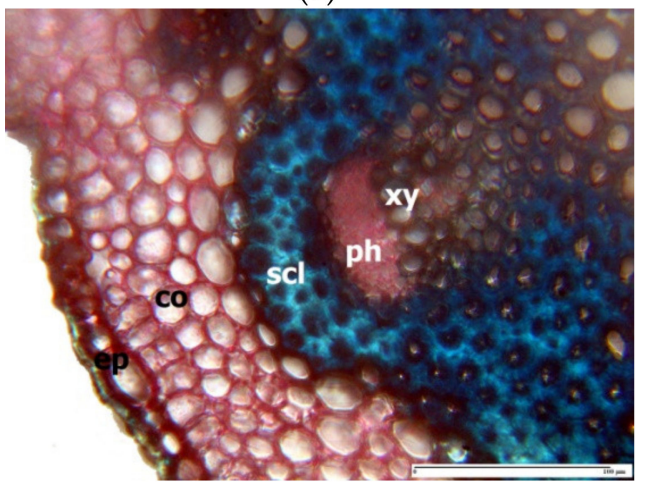

(c)

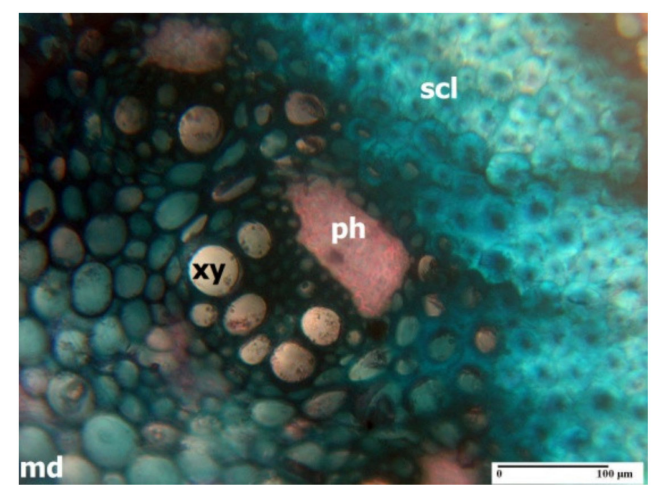

(b)

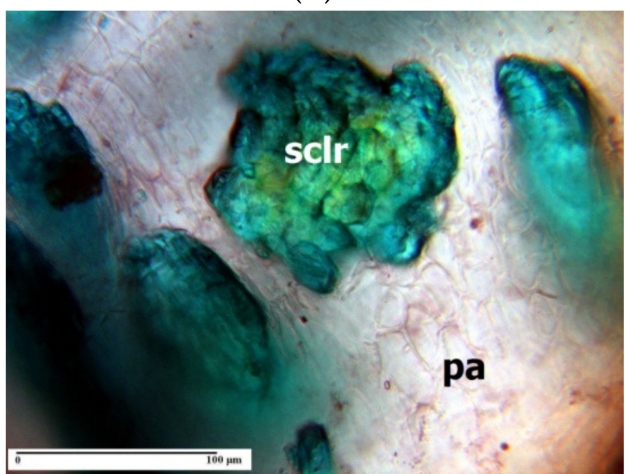

(d)

Figure 2. Cross-section through the rhizome of Limonium girardianum (a), aerial stem of Limonium girardianum (b), aerial stem of Limonium narbonense (c), and groups of sclereids located in the rhizome' cortex of Limonium girardianum (Guss.) Fourr. (d); co-cortex; ep-epidermis; pa-parenchyma; ph r-phloemic ring; scl r-sclerenchyma ring; $x y$-xylem vessel; sclr-sclereid; md-medulla; ph—phloem; scl—sclerenchyma; $x y$-xylem vessel; ph—phloem.

Groups of sclereids are present in the rhizome of several species of Limonium, such as L. furfuraceum (Figure 1a), L. girardianum (Figure 2d), L. gmelinii [76], or L. brasiliense [77]. 
The presence of well-developed sclerenchyma in the underground organs of Limonium halophytic species could be interpreted as an adaptation to the harsh environmental conditions of the plants' natural habitats [71]. Indeed, sclerenchymatic rings, as well as the groups of sclereids found in the rhizome, could confer to the underground system the mechanical resistance needed to penetrate the dry, compact soil to reach the water table.

Another interesting anatomical feature in Limonium halophytes is the presence of mechanical idioblasts. They have been found in the lamina of L. girardianum (Figure 3), L. gmelinii [79], L. gmelinii ssp. hungaricum, L. anfractum (C.E.Salmon) C.E.Salmon [83], L. lopadusanum Brullo and L. albidum (Guss.) Pignatti [81]. These structures can be differently nominated: mechanical idioblasts [75], spicular cells (stereids, sclereids, idioblasts) [71], sclereids in the form of idioblasts [80], sclereidal idioblasts [81], sclereides [84] and likely play a mechanical role, conferring the coriaceous aspect of the leaves of Limonium species [71].

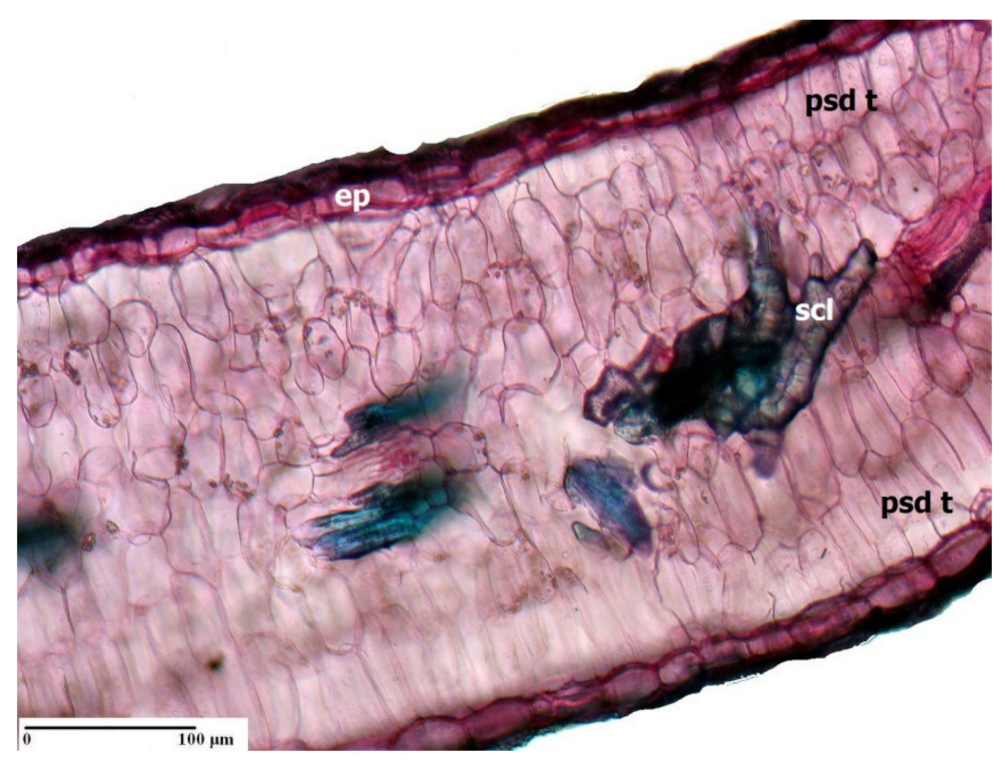

Figure 3. Branched sclereids in the lamina of Limonium girardianum; ep—epidermis; psd $\mathrm{t}$-palisade tissue; scl-branched sclereid.

A typical anatomical trait of Plumbaginaceae is the presence of glands: chalk glands (Mettenius or Licopoli glands-salt glands-Figure $4 \mathrm{a}-\mathrm{d}$ ) and mucilage glands located on leaves and stems [71]. This feature classifies halophyte species from Plumbaginaceae in the group of recretohalophytes (that secrete salt via salt bladders and salt glands-the case of Limonium species). Salt glands are particularly well-known and of great scientific interest from the historical (see [73] and references therein), anatomical [71,73,78,85], physiological [86] and evolutionary $[87,88]$ points of view. Within the recretohalophytes from Plumbaginaceae, recent data report 48 species of Limonium to have salt glands [87]. Even though the history of anatomical description of salt glands dates back to the mid-19th century [73], there is no consensus regarding the number of cells that build up a salt gland. Caperta et al. [87] indicated that a complex of 16-celled salt gland structure in Limonium species is commonly reported in the literature. However, other arrangements of 10 and 20 cells have also been described. Nevertheless, these differences in the registered number of cells of a salt gland in Limonium are partly due to the lack of standard definition of the cells that constitute the salt gland. Moreover, sometimes glands observed in front view (on the epidermis surface) do not reveal the entire architecture of the gland, as several cells remain 'hidden' below the surface. 


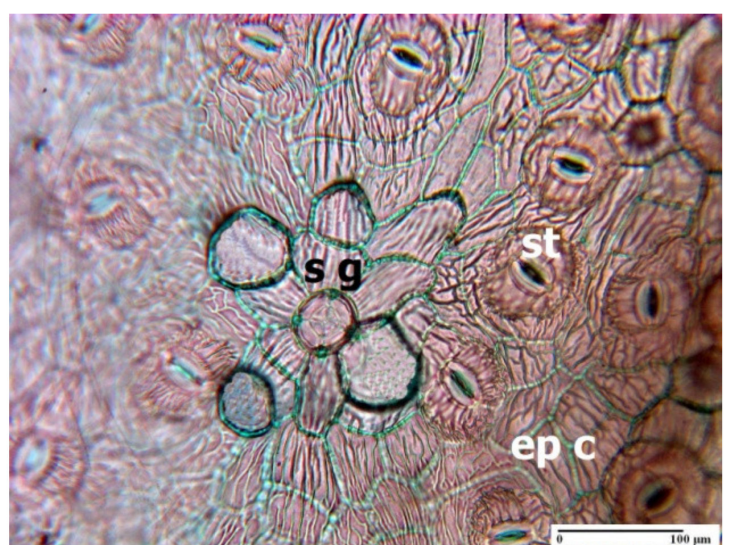

(a)

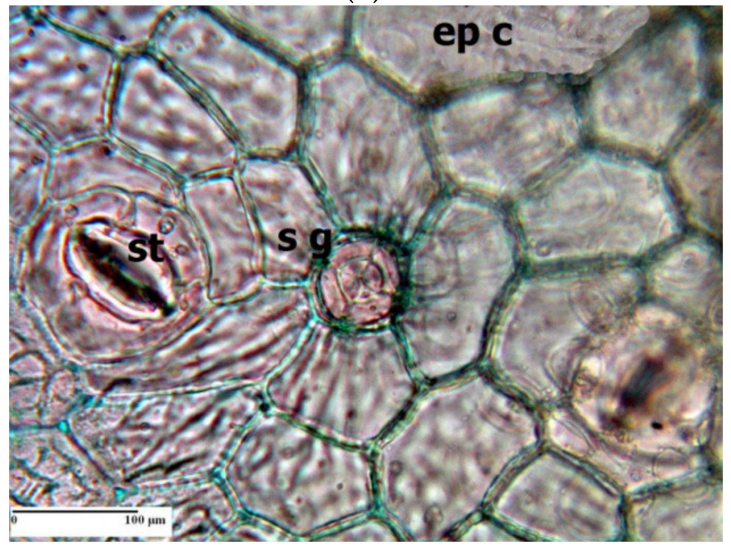

(c)

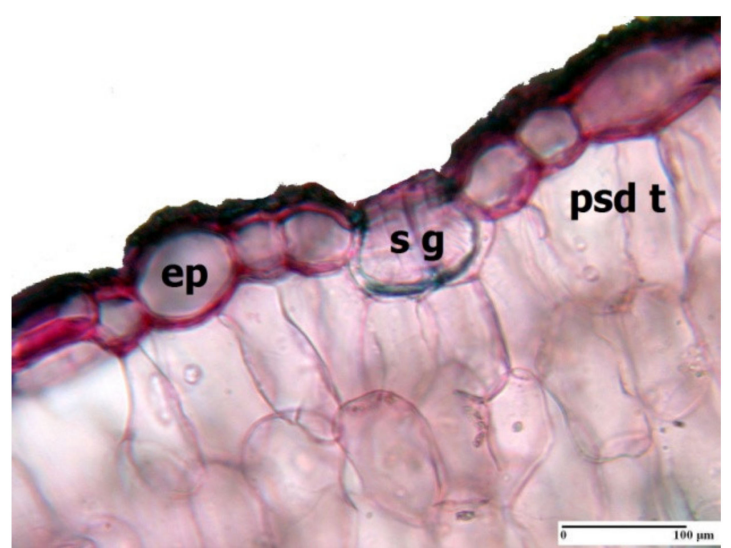

(b)

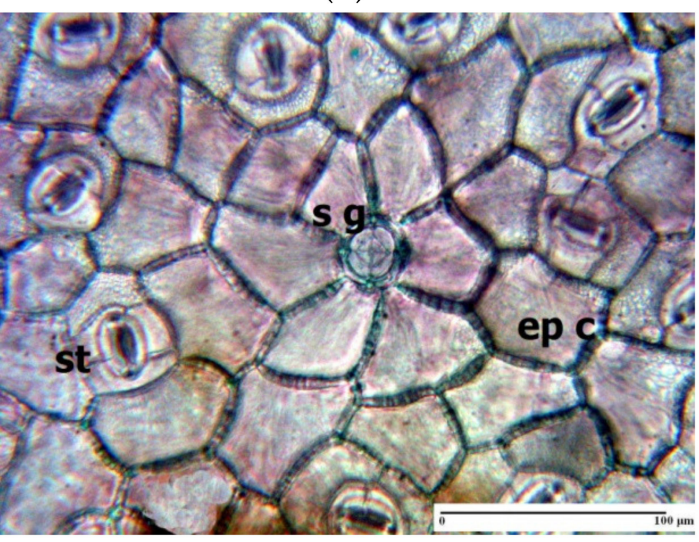

(d)

Figure 4. Salt gland in the epidermis of Limonium furfuraceum (surface view) (a), Limonium girardianum (cross section) (b), Limonium narbonense (surface view) (c), and Limonium gmelinii (surface view) (d); ep c-epidermal cells; s g-salt gland; st-stomata; psd t-palisade tissue

\section{Seed Germination under High Salinity, and Recovery of Germination}

High salinities represent a constraint for the germination of the seeds of all plants, including halophytes. Although adult halophytes may withstand very high salt concentrations in their natural habitats, their seeds usually germinate when soil salinity is alleviated $[38,89,90]$. Halophytes broadly vary in their limits of salt concentrations suitable for germination, and many show optimal germination percentages in freshwater or at salinities below $100 \mathrm{mM} \mathrm{NaCl}$ [38]. However, the seeds of some highly salt-tolerant species, especially succulent halophytes, can germinate at concentrations equivalent to that of seawater or above, up to $1.7 \mathrm{M} \mathrm{NaCl}$ [91]. There is a seasonal variation of the soil salinity in many natural environments, which is higher during summer due to accentuated evaporation. Seed germination in arid and semi-arid regions usually occurs after the rains reduce surface soil salinity [91,92]. Halophytes from temperate salt marshes maintain a persistent soil seed bank and germinate in spring when salinity is alleviated [89,93]. At the seed germination stage, recretohalophytes generally are more susceptible to high salt concentrations than the succulent ones, and less than $20 \%$ can germinate above seawater salinity [91].

Several micro-endemic species of Limonium from SE Iberian Peninsula have been analysed, and germination percentages and rates usually decreased with increased salinity and temperature. In several species, optimal germination was registered in distilled water and at low salinity $(100 \mathrm{mM} \mathrm{NaCl})$, at $20 / 10{ }^{\circ} \mathrm{C}$, with a $14 / 10 \mathrm{~h} \mathrm{light/darkness}$ photoperiod [94-98]. The percentage and rate of germination decreased with an increase in salinity and temperature in L. cossonianum Kuntze from wetlands in SE Spain [94]. A similar behaviour has been observed in L. insigne (Coss.) Kunze from coastal cliffs, littoral 
steppes and dry inland areas [95], or in L. tabernense Erben, restricted to arid environmental conditions in the Tabernas Desert (SE Spain) [96]. From the same geographic area, optimal germination was registered in distilled water at $15{ }^{\circ} \mathrm{C}$ constant temperature and $12 \mathrm{~h}$ light photoperiod in L. mansanetianum M.B.Crespo \& Lledó from gypsum areas [97]; also, at alternating temperatures of $20{ }^{\circ} \mathrm{C}$ (under light conditions) and $10{ }^{\circ} \mathrm{C}$ (in the dark) in $L$. supinum (Girard) Pignatti from arid habitats of the same region [98]. In all these species, an interactive negative effect of temperature and salinity on final germination percentage and germination rate was established, indicating that the germination response to salinity depends on the temperature. In two other local endemics, L. dufourii (Girard) Kuntze and the recently described L. albuferae P.P.Ferrer, R.Roselló, M.Rosato, Rosselló \& E. Laguna, from salt marshes near Valencia in E Spain, germination was drastically reduced at 150 $\mathrm{mM} \mathrm{NaCl}$ [99]. Maximal germination percentages and rates were also reported in control treatments in L. emarginatum (Willd.) Kuntze, an endangered and endemic halophyte of the Strait of Gibraltar [100].

In seeds of four other species sampled from the Valencia region, the temperature did not have a drastic effect on their germination [101]. In two of these species, the local endemic L. santapolense Erben and the common Mediterranean L. virgatum (Willd.) Fourr, low salinity (50 mM NaCl) stimulated germination; in the latter species, an increase of $80 \%$ in the percentage of germination was observed in the presence of $100 \mathrm{mM}$ salt. Seeds of the widespread L. narbonense showed optimal germination up to $200 \mathrm{mM} \mathrm{NaCl}$; however, in L. girardianum, present in salt marshes in E Spain and S France, significant inhibition of germination was observed already at $50 \mathrm{mM} \mathrm{NaCl}$ [16]. The pattern of germination of these four species was correlated with their geographic distribution. Limonium narbonense and L. virgatum, which are widespread throughout the Mediterranean region, can germinate at high salt concentrations and, consequently, colonise habitats with higher soil salinity, avoiding competition with less tolerant species. On the other hand, the endemic L. santapolense and L. girardianum are less salt-tolerant at the seed germination stage, and more competitive only at lower salt concentrations; therefore, they are restricted to smaller areas.

These results are summarised in Figure 5. As mentioned above, the highest germination percentages were found in the seeds from control treatments or at a relatively low concentration of 50 and $100 \mathrm{mM} \mathrm{NaCl}$. With a few exceptions, $200 \mathrm{mM} \mathrm{NaCl}$ drastically inhibited germination. Complete inhibition was registered at $300-400 \mathrm{mM} \mathrm{NaCl}$ in the most susceptible taxa, and at $500 \mathrm{mM}$ practically no germination was observed in any of the analysed species.

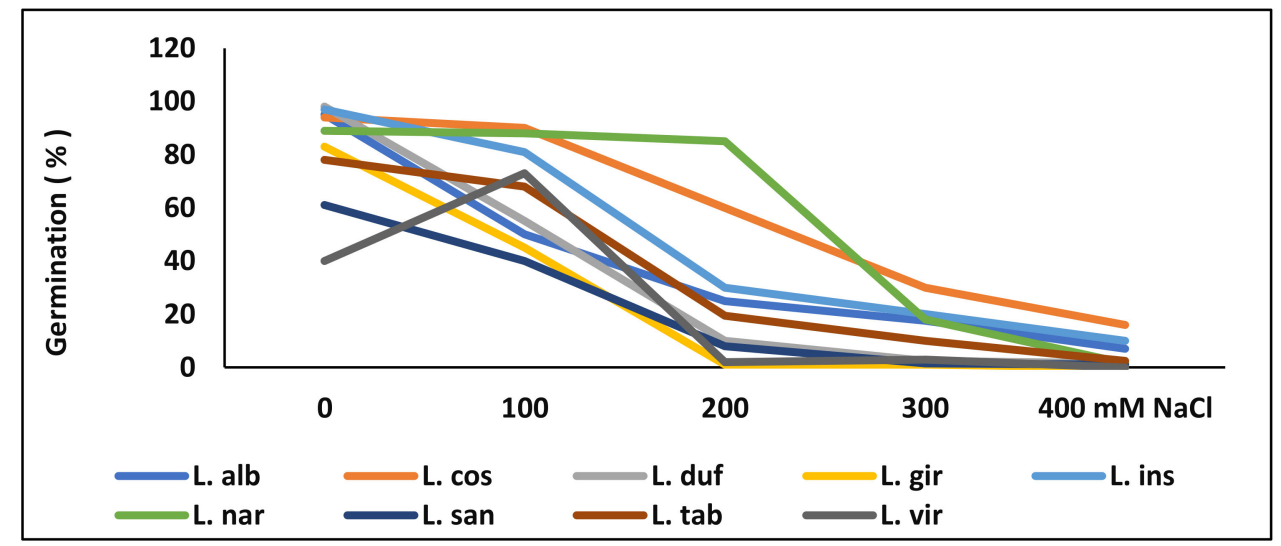

Figure 5. Final germination percentages of Limonium seeds after 20-25 days of exposure to the indicated salt concentrations. Abbreviations: L. albuferae (L. alb); L. cossonianum (L. cos.); L. dufourii (L. duf.); L. girardianum (L. gir.); L. insigne (L. ins); L. narbonense (L. nar); L. santapolense (L. san); L. tabernense (L. tab.); L. virgatum (L. vir). Based on [16,94-96,99]

In two endemic Limonium species from Turkey, L. lilacinum (Boiss. \& Balansa) Wagenitz and L. iconicum (Boiss. \& Heldr.) Kuntze, the highest germination was obtained in distilled 
water at $15 / 25^{\circ} \mathrm{C}$ and $20 / 30^{\circ} \mathrm{C}$, in a $12 \mathrm{~h}$ light photoperiod. Germination was drastically inhibited by $300 \mathrm{mM}$ and higher $\mathrm{NaCl}$ concentrations, and by the lower thermoperiod $\left(10 / 20{ }^{\circ} \mathrm{C}\right)$ in both, control and salt treatments. The germination rate increased with an increase in temperature and decreased with increasing salinity, whereas light stimulated germination in both species [102]. Light was also reported to stimulate germination of seeds of the annual L. lobatum (L. fil.) Chaz, collected in Australia, where this Mediterranean species is becoming an aggressive weed. The best germination was registered in the absence of salt, in a range of temperatures between 10 and $30^{\circ} \mathrm{C}$; in the presence of $230 \mathrm{mM} \mathrm{NaCl}$, germination was reduced by half but some seeds germinated even at $480 \mathrm{mM} \mathrm{NaCl} \mathrm{[103].}$

Some additional reports also indicated a great tolerance to salinity during germination in several Limonium species. In L. stocksii, from the subtropical maritime desert of Karachi, some seeds germinated even at $500 \mathrm{mM} \mathrm{NaCl}$ at the optimal temperature regime of $20 / 30{ }^{\circ} \mathrm{C}$; germination was maximal in control, 100 and $200 \mathrm{mM} \mathrm{NaCl}$, and $60 \%$ of the seeds germinated in the presence of $300 \mathrm{mM}$ salt. Also, in L. axillare (Forssk.) Kuntze, from desert areas in Saudi Arabia, even though part of the seeds germinated at high salt concentration, a drastic reduction of germination percentages was registered at a lower concentration of $170 \mathrm{mM} \mathrm{NaCl}$ [104]. Germination of desert halophytes usually increases with temperature, contrary to those from humid habitats, which germinate better at a lower temperature [91]. However, the highest tolerance to salinity during germination in Limonium was reported in L. vulgare Mill., where seed germination was still registered at the very high concentration of $1.4 \mathrm{M} \mathrm{NaCl}$, albeit drastically reduced to $10 \%$ of the non-stressed control seeds [105].

Contrary to glycophytes seeds, which cannot withstand long exposure to saline environments, halophytes possess the ability to recover from salt stress and germinate after being exposed to hyper-saline conditions, a strategy of great selective advantage. In habitats with fluctuant salinity like salt marshes, halophytes provide a viable soil seed bank; germination occurs when there is an alleviation of salinity, generally in spring in temperate climates and after rainy periods in dessert areas [89]. However, this recovery capacity of halophyte seeds varies quantitatively in different species. Indeed, most halophytes show a substantial recovery of germination when stress conditions are alleviated [38,91,93,106-108]. A $60 \%$ to $70 \%$ recovery of final germination was recorded in L. emarginatum, although seed viability decreased under hypersaline conditions [100], as in L. tabernense [96]. In L. albuferae and L. dufourii, recovery of germination percentages reached $60-80 \%$ and $80-90 \%$, respectively, whereas the germination rate increased in both [99]. Recovery was complete in L. stocksii seeds exposed up to $500 \mathrm{mM} \mathrm{NaCl}$ [61]. In L. santapolense, L. narbonense, L. giradianum and L. virgatum, full recovery of germination was reported, reaching values similar to those of control seeds germinated in water. Significant stimulation of germination was observed in L. virgatum after exposure to $150 \mathrm{mM} \mathrm{NaCl}$ and, to a lesser extent, in $L$. girardianum seeds pre-treated with $50 \mathrm{mM} \mathrm{NaCl}$ [16].

\section{Plant Growth under Controlled Experimental Conditions}

Growth reduction is the first and most general response of plants to environmental stress conditions, such as drought or salinity, as plants use their metabolic precursors and energetic resources to activate defence mechanisms instead of biomass accumulation [25]. The majority of halophytes, and all glycophytes, grow optimally in the absence of salt. Only in a few, extremely salt-tolerant halophytes, growth is stimulated by low or moderate salinity, although still inhibited in the presence of salt above a higher, species-specific concentration threshold [109]. For this reason, assessment of the effect of salt stress on growth parameters in different species is a useful tool for ranking their relative degree of salt tolerance [110].

Figure 6 summarises the effect of salinity and drought on the growth of six different Limonium species evaluated in our laboratory. Seeds of all the species, already mentioned in the previous section, were sampled in salt marshes in the Albufera Natural Park, near Valencia in eastern Spain, except for those of the endemic L. santapolense, present in a 
more southern location, in the Alicante province. Limonium albuferae and L. dufourii are endangered local endemics included in conservation programmes. The remaining species have a broader distribution, L. girardianum in S France and E Spain, and L. virgatum and L. narbonense throughout the Mediterranean. Plants grown from the seeds were subjected to salt and water stress treatments under controlled greenhouse conditions. Growth was generally stimulated at 200 and even $400 \mathrm{mM} \mathrm{NaCl}$ and was inhibited only at higher salt concentrations. Under water stress, a significant reduction of leaf fresh weight was registered in L. santapolense and L. narbonense [111], but mostly in plants with leaves of a larger size, such as L. albuferae and L. dufourii [99].

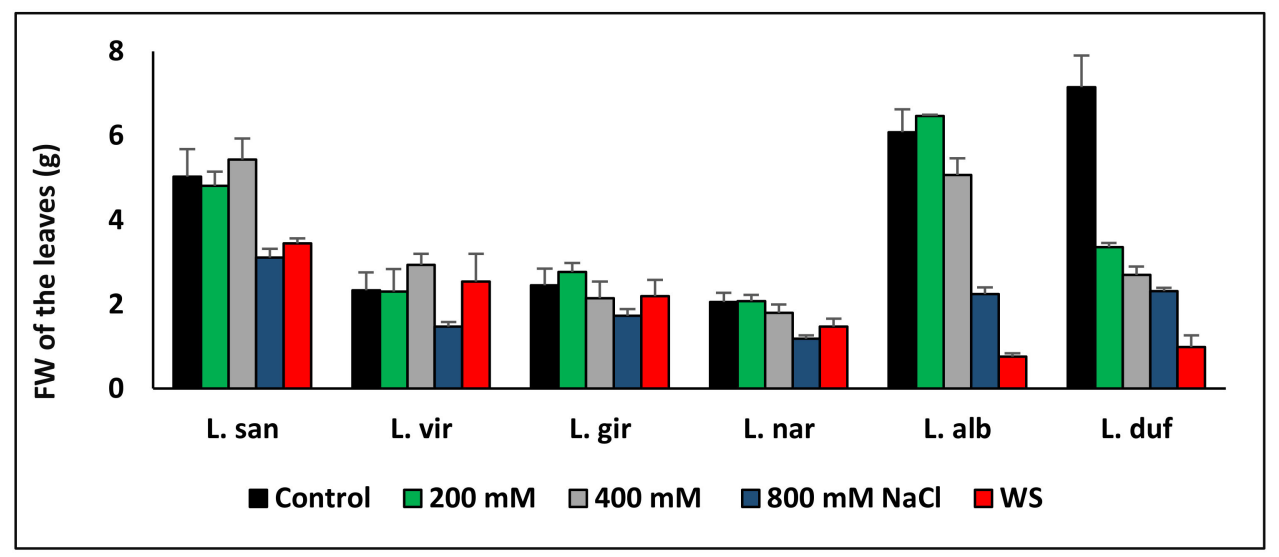

Figure 6. Mean leaf fresh weight (FW) of Limonium plants after one-month stress treatments. Salt treatments at the $\mathrm{NaCl}$ concentrations indicated above. Water stress (WS) was applied by complete withholding of irrigation- Abbreviations: L. albuferae (L. alb); L. dufourii (L. duf.); L. girardianum (L. gir.); L. narbonense (L. nar); L. santapolense (L. san); L. virgatum (L. vir). Based on [16,111]

Also, a remarkable salt tolerance was reported in the desert species L. stocksii, which maintained constant growth up to $300 \mathrm{mM} \mathrm{NaCl}$, and only higher salt concentrations inhibited biomass accumulation [112]; a similar behaviour was observed for L. sinense (Girard) Kuntze [113]. In L. pectinatum (Aiton) Kuntze, a species of Canarian origin and used as ornamental worldwide, growth was stimulated at $100 \mathrm{mM} \mathrm{NaCl}$ and showed similar values to those in control plants in the presence of $200 \mathrm{mM} \mathrm{NaCl}$ [114]. Similarly, the growth of L. delicatulum (Girard) Kuntze was stimulated at 50, 100 and $200 \mathrm{mM} \mathrm{NaCl}$ when compared with control plants, and drastically reduced only at salt concentrations exceeding $200 \mathrm{mM} \mathrm{NaCl}$ [115].

Lower salt tolerance was reported in a comparative study on two cultivated species, $L$. perezii and L. sinuatum. Growth of the former species was inhibited even at low salinities, whereas the latter showed a somewhat higher tolerance; nevertheless, both were able to complete their life cycles at concentrations above $300 \mathrm{mM} \mathrm{NaCl}$, thus behaving as true halophytes [116]. Analysis of seedlings' responses to salt in L. bicolor, with a native distribution in Mongolia and NE China, showed $100 \mathrm{mM} \mathrm{NaCl}$ as the optimal salt concentration for plant growth [117], and no injuries were observed at concentrations up to $150 \mathrm{mM}$ [118]. In L. latifolium, a native of SE Europe and W Asia and widely used as ornamental, the highest growth rate was reported in control plants, but the plants survived and remained vigorous when subjected to treatments with $\mathrm{NaCl}$ up to $400 \mathrm{mM}$ for one month [119]. Most Limonium species, especially those used as ornamentals, grow better in control conditions or at low salinities, but some of the wild species are much more salt-tolerant, to a degree similar to that of extremophiles, such as Suaeda maritima (L.) Dumort. [120-122].

\section{Ion Transport and Accumulation}

Recretohalophytes can secrete toxic ions through salt glands and trichomes, and many studies confirm this specific feature in Limonium (e.g., $[123,124])$. In a comparative study on a wild species and a cultivated hybrid of this genus, the more tolerant wild L. pectinatum 
had higher excretion rates of $\mathrm{Na}^{+}$and $\mathrm{Cl}^{-}$than the hybrid; both secrete only small amounts of $\mathrm{K}^{+}$[114], as salt glands are highly selective for $\mathrm{Na}^{+}$and $\mathrm{Cl}^{-}$[125].

Although it has been long known that Limonium species lower the ionic activity in the photosynthetic parenchyma through their excretory glands [126], the genus is also reported as a salt accumulator (e.g., $[16,116,127])$. One of the main differences between monocotyledonous and dicotyledonous halophytes is related to the control of ion transport and homeostasis. In salt-tolerant monocots, as in all glycophytes, the primary mechanism of stress resistance is based on blocking the transport of toxic ions $\left(\mathrm{Na}^{+}\right.$and $\left.\mathrm{Cl}^{-}\right)$to the aerial part of the plants. On the contrary, in the halophytic dicots, there is an active uptake, transport to the leaves and compartmentalisation in vacuoles [25,26]. Reports on different Limonium species support this 'dicot model', as $\mathrm{Na}^{+}$and $\mathrm{Cl}^{-}$concentrations increased in parallel to the concentration of $\mathrm{NaCl}$ applied, both in roots and, especially, in their aboveground organs $[16,99,127]$. The same results have been reported in other stress-tolerant species [128-130]. Tester and Davenport [131], considered that constant levels of $\mathrm{NaCl}$ in roots are maintained by its export to the shoots; this is also a mechanism to reduce the toxic effects of salt at the root level [132], and its use as cheap osmoticum in the shoots [33,133]. Ion toxicity in the cytoplasm is avoided by compartmentalisation of $\mathrm{Na}^{+}$and $\mathrm{Cl}^{-}$in vacuoles [134].

Results obtained in our laboratory on the analysed species of Limonium are shown in Figures 7 and 8 . In the six species, the contents of all quantified ions increased in parallel with the increase in external salinity in both, belowground and aboveground organs, but were significantly lower in the roots than in the leaves. The most remarkable increase was registered in the leaves of the least tolerant $L$. dufourii (Figure 7). Interestingly, this species also accumulated $\mathrm{Na}^{+}$in the leaves of plants subjected to a water stress treatment (Figure 7, and unpublished data). Accumulation of $\mathrm{Na}^{+}$at low soil $\mathrm{NaCl}$ concentrations has been recently proposed as an essential mechanism of drought tolerance in the desert xerophyte Zygophyllum xanthoxylum (Bunge) Engl. [135].

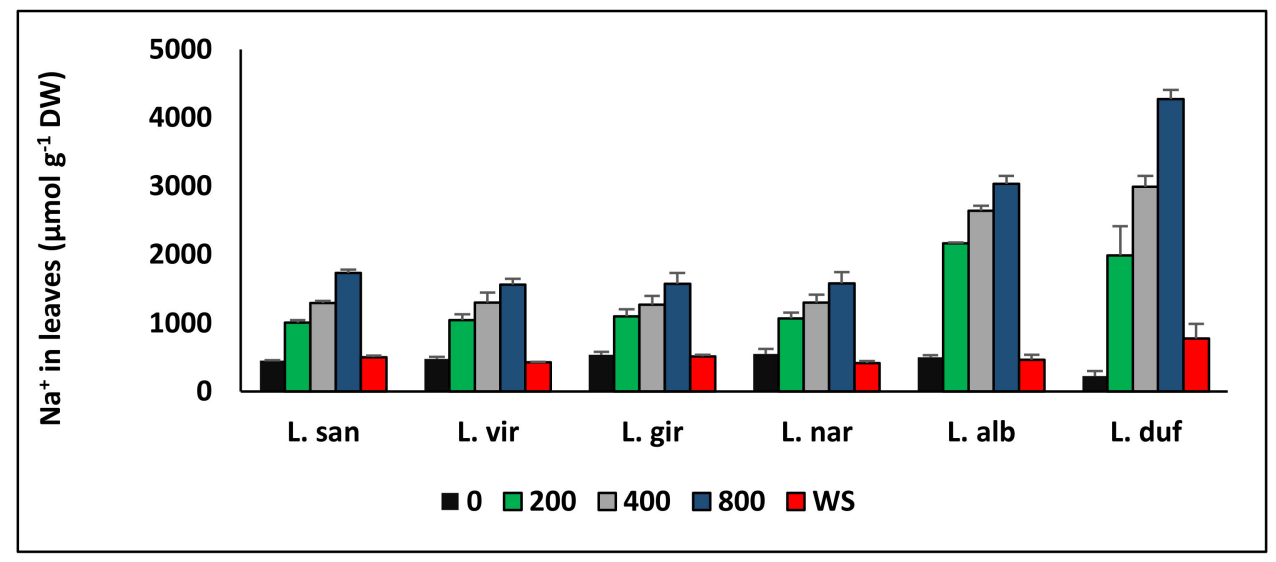

Figure 7. Accumulation of $\mathrm{Na}^{+}$in foliar tissue of Limonium plants after one-month stress treatments. Salt treatments at the $\mathrm{NaCl}$ concentrations indicated above. Water stress (WS) was applied by complete withholding of irrigation. Abbreviations: L. albuferae (L. alb); L. dufourii (L. duf.); L. girardianum (L. gir.); L. narbonense (L. nar); L. santapolense (L. san); L. virgatum (L. vir). Based on ([16,99] and unpublished data). 


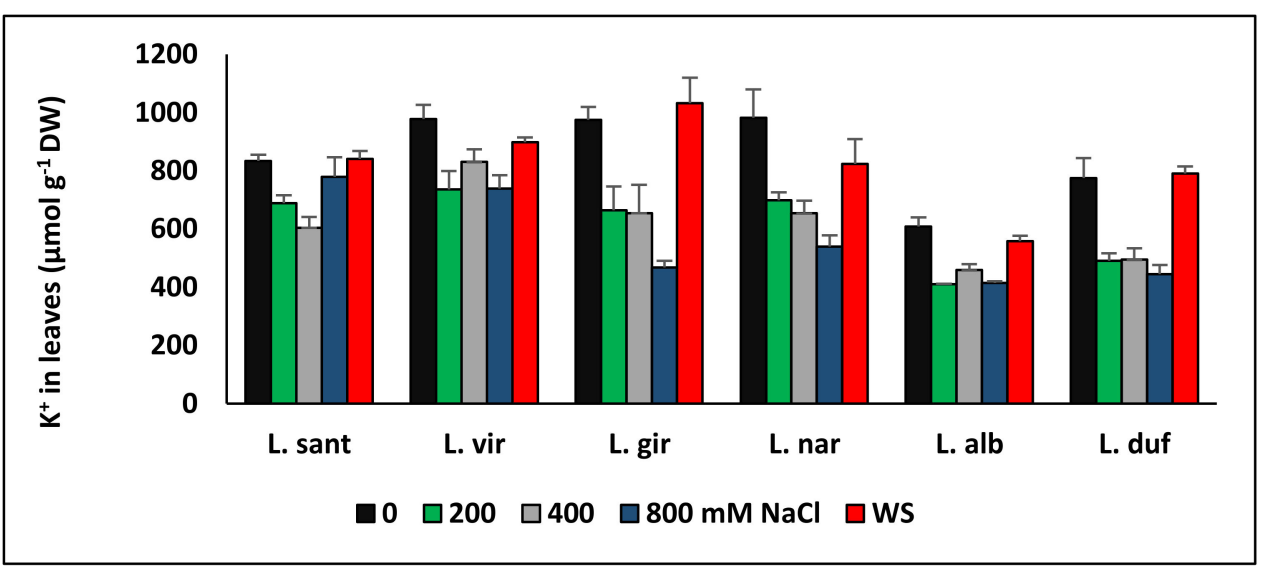

Figure 8. Accumulation of $\mathrm{K}^{+}$in foliar tissue of Limonium plants after one-month stress treatments. Salt treatments at the $\mathrm{NaCl}$ concentrations indicated above. Water stress (WS) was applied by complete withholding of irrigation. Abbreviations: L. albuferae (L. alb); L. dufourii (L. duf.); L. girardianum (L. gir.); L. narbonense (L. nar); L. santapolense (L. san); L. virgatum (L. vir). Based on ([16,99] and unpublished data).

High levels of $\mathrm{Na}^{+}$can be associated with toxic effects, causing a reduction in seedling emergence and survival, as well as in the contents of other ions, such as $\mathrm{K}^{+}$and $\mathrm{Ca}^{2+}$, as shown by Carter et al. [136] in L. perezii. In a comparative study on three halophytes from Brittany coast (Limonium latifolium, Matricaria maritima L. and Crambe maritima L.) the smallest accumulation of $\mathrm{Na}^{+}$was found in the most tolerant species, L. latifolium [119], in agreement with the salt tolerance mechanism discussed above.

Usually, an increase in the concentration of $\mathrm{Na}^{+}$is associated with a reduction of $\mathrm{K}^{+}$, as the two cations compete for the same binding sites and use the same transport proteins. Moreover, an excess of $\mathrm{Na}^{+}$causes the depolarisation of the plasma membrane, inducing the activation of outward rectifying $\mathrm{K}^{+}$channels and, therefore, the loss of cellular $\mathrm{K}^{+}$[137]. However, many Limonium species have the ability to activate the transport of $\mathrm{K}^{+}$to the leaves in response to salt treatments, leading to a smaller reduction or the maintenance of constant leaf levels of this cation [99], or even an increase over the control at higher external salinity [16]. Similar results have also been reported in halophytes of the genus Plantago, both in the field [138] and in the greenhouse [110].

As shown in Figure 8, foliar $\mathrm{K}^{+}$levels in L. albuferae and L. dufourii were lower in plants subjected to salt treatments than in their controls, but in the other species, the reduction was smaller. The strongest reduction in $\mathrm{K}^{+}$was registered in the most salt-sensitive $L$. dufourii, which also showed a relatively higher accumulation of $\mathrm{Na}^{+}$in salt-stressed plants; therefore, in this species a higher $\mathrm{Na}^{+} / \mathrm{K}^{+}$ratio was observed in the leaves of plants subjected to the highest concentration of $800 \mathrm{mM} \mathrm{NaCl}$. Similar findings were reported in a comparative study on two other Limonium species, L. perezii and L. sinuatum; the latter, which is the most tolerant, showed a high selectivity of $\mathrm{K}^{+}$over $\mathrm{Na}^{+}$[116]. Maintaining a balanced cytosolic $\mathrm{Na}^{+} / \mathrm{K}^{+}$ratio, together with high foliar levels of $\mathrm{K}^{+}$, is regarded as an essential mechanism for salt tolerance $[139,140]$. In plants from the water stress treatment the variations were small in respect to controls, in L. santapolense $\mathrm{K}^{+}$values remained practically unchanged and in L. girardianum even increased in water-stressed plants.

\section{Osmolyte Synthesis}

The accumulation of inorganic ions in vacuoles is compensated by that of compatible solutes or osmolytes in the cytoplasm. Osmolytes are simple, non-toxic organic molecules, which do not interfere with cellular metabolism even at high intracellular concentrations. They play several essential roles in the responses of plants to abiotic stress, besides their primary function in osmotic adjustment, including the direct stabilisation of proteins and macromolecular structures, as 'reactive oxygen species' (ROS) scavengers or signalling 
molecules $[28,141]$. Osmolytes are chemically diverse, including amino acids and derivatives, such as proline, methylated proline and related compounds; quaternary ammonium compounds, such as glycine betaine and other betains; soluble sugars, such as glucose, fructose, sucrose, trehalose, raffinose or fructans; and polyols or sugar alcohols, such as sorbitol, mannitol, glycerol, inositol and methylated inositols [24,28]. A concomitant synthesis of different osmolytes is well-known in halophytes [142-145] but the highest diversity is found within the Plumbaginaeceae family, and especially in the genus Limonium [146]. Many species of this well-known halophytic genus have been analysed, and a wide variety of compounds has been reported as compatible solutes, which are summarised in Table 1.

Table 1. Main compatible solutes reported in Limonium species. Only those present at high concentrations or considered as significant in the original publications are included.

\begin{tabular}{|c|c|c|c|}
\hline Species & Treatment & Compatible Solutes & Reference \\
\hline L. albuferae & salt & Glu, Fru, Pro, GABA & [99] \\
\hline \multirow{2}{*}{ L. axillare } & field & $\beta A B$, Pro & [147] \\
\hline & field & Pro & [148] \\
\hline L. anatolicum & field & $\beta \mathrm{AB}, \mathrm{Cho}$, Glu, Fru; Pro & [149] \\
\hline L. aureum & salt & $\beta \mathrm{AB} ; \mathrm{COS}$ & [150] \\
\hline L. diffusum & field & $\mathrm{PB}$ & [151] \\
\hline L. bicolor & salt & Pro & [152] \\
\hline L. dufourii & salt & Pro, GABA & [99] \\
\hline L. dumosum & & $\beta A B ; C O S ;$ Pro; Tryamine & [153] \\
\hline L. ferulaceum & & PB 146 & [151] \\
\hline \multirow{3}{*}{ L. girardianum } & salt & Pro, Fru, Suc & [16] \\
\hline & drought & Pro, GB, Glc & [111] \\
\hline & field & Pro, Fru & {$[17]$} \\
\hline L. globuliferum & field & Pro, $C O S, \beta A B$ & {$[142,151]$} \\
\hline \multirow{2}{*}{ L. iconicum } & field & $\mathrm{GB}, \mathrm{COS}, \beta \mathrm{AB}$ & [142] \\
\hline & field & GB, $\beta A B, C h o$, Glu, Fru & [149] \\
\hline \multirow{3}{*}{ L. latifolium } & field & $\beta \mathrm{AB} ; \mathrm{COS}$ & [151] \\
\hline & Hoagland & BAB; COS; Pro & [153] \\
\hline & salt & $\begin{array}{l}\text { Gln, Suc, Fru, Glc, cInos, } \\
m \text { Inos }\end{array}$ & [143] \\
\hline L. lilacinum & field & $\beta A B$, Cho, Glu, Fru, Pro & [149] \\
\hline \multirow{3}{*}{ L. gmelinii } & Hoagland & $\beta \mathrm{AB} ; \mathrm{COS}$; Pro, Tryamine; Glutamate; Methionine & [153] \\
\hline & field & Pin & [154] \\
\hline & field & Pin, $\beta A B, C O S$ & [155] \\
\hline L. liniifolium & drought & Pro, oxalic acid & [123] \\
\hline L. guyonianum & field & $\mathrm{PB}$, Hydroxyproline betaine & [151] \\
\hline L. macrophyllum & field & Pro, COS & [151] \\
\hline L. mucrontaum & field & Pro, COS & [151] \\
\hline L. monopetalum & & Hydroxyproline betaine; PB & [151] \\
\hline \multirow{3}{*}{ L. narbononense } & & Pro, GB, Fru & [16] \\
\hline & drought & $\mathrm{R}, \mathrm{GB}$ & [111] \\
\hline & field & Pro, Gb, Fru & {$[17]$} \\
\hline L. pectinatum & field & Pro, COS & [151] \\
\hline \multirow{3}{*}{ L. perezii } & salt & $\mathrm{GB}, \mathrm{COS}$ & [151] \\
\hline & & Glutamate, Tyrosine, Methionine, Ornithine, GB; COS & [153] \\
\hline & salt & cInos, $m$ Inos, Fru, Glc, Suc & [156] \\
\hline
\end{tabular}


Table 1. Cont.

\begin{tabular}{|c|c|c|c|}
\hline Species & Treatment & Compatible Solutes & Reference \\
\hline L. plumosum & field & Pro, COS & [151] \\
\hline L. puberulum & field & Pro, COS & [151] \\
\hline L. salicorniaceum & field & Hydroxyproline betaine & [151] \\
\hline L. santapolense & $\begin{array}{l}\text { salt } \\
\text { drought } \\
\text { field }\end{array}$ & $\begin{array}{l}\text { GB, Fru, Suc } \\
\text { Pro, Suc, Fru, GB } \\
\text { Suc, Fru }\end{array}$ & $\begin{array}{l}{[16]} \\
{[111]} \\
{[18]}\end{array}$ \\
\hline L. sinuatum & $\begin{array}{l}\text { salt } \\
\text { Hoagland } \\
\text { salt } \\
\text { salt }\end{array}$ & $\begin{array}{l}\text { GB, COS } \\
\text { GB, COS, Glutamate } \\
\text { cInos, mInos Fru, Glc, Suc } \\
\text { Pro }\end{array}$ & $\begin{array}{l}{[150]} \\
{[153]} \\
{[156]} \\
{[157]}\end{array}$ \\
\hline L. tataricum & Hoagland & $\beta \mathrm{AB} ; \mathrm{COS} ;$ Pro & [153] \\
\hline L. virgatum & $\begin{array}{l}\text { salt } \\
\text { drought } \\
\text { field }\end{array}$ & $\begin{array}{l}\text { Pro, GB, Suc } \\
\text { GB } \\
\text { Fru, GB, Pro }\end{array}$ & $\begin{array}{c}{[16]} \\
{[111]} \\
{[17]}\end{array}$ \\
\hline L. vulgare & $\begin{array}{l}\text { salt } \\
\text { Hoagland }\end{array}$ & $\begin{array}{l}\beta \mathrm{AB} ; \mathrm{COS} \\
\text { Tryamine, Pro; } \beta \mathrm{AB} ; \mathrm{COS}\end{array}$ & $\begin{array}{l}{[150]} \\
{[153]}\end{array}$ \\
\hline
\end{tabular}

Abbreviations: Glucose (Glc), Fructose (Fru), Proline (Pro); $\gamma$-aminobutyric acid (GABA), $\beta$-alanine betaine ( $\beta$ AB), Choline-O-sulfate (COS), choline (Cho), Proline betaine (PB), Sucrose (Suc), Glycine betaine (GB); Glutamine (Gln), chiro-Inositol (cInos), myo-Inositol (mInos), Pinitol (Pin).

Proline (Pro), one of the most common osmolytes in plants, has different biological functions in abiotic stress tolerance mechanisms, as it has also been described for other compatible solutes. Pro acts in osmotic adjustment under stress; as a low-molecularweight chaperon, for example, in protecting plasma membrane integrity and its associated transporter proteins; as a ROS scavenger, with singlet oxygen quenching capacity; and/ or a signalling molecule in the transduction of stress signals $[27,158]$. Proline has been detected in many Limonium species, generally at low concentrations under control conditions but showing a significant increase in plants subjected to water deficit or salt stress treatments. However, Gagneul et al. [143] questioned its role as compatible solute involved in salt tolerance in L. latifolium. These authors considered Pro, together with $\beta$-alanine betaine and choline-O-sulfate, rather as 'temporally associated with expression of more important traits for coping with salinity', so that the observed variations in Pro levels could be related to successive damage and repair at the mitochondrial step of Pro oxidation [143].

Glycine betaine (GB) is another widely distributed osmolyte in plants, present at high concentrations in many halophytes, especially in members of the Chenopodiaceae and salt-tolerant species of the Poaceae [159]. Glycine betaine is synthesised mainly from choline, and GB accumulators have particular adaptations in choline and methyl group biogenesis that are not present in other plants [146]. Choline-O-sulphate, reported in all Plumbaginaceae species [151], is synthesised from choline by a salt-inducible choline sulphotransferase [160]. A possible explanation for this particularity is that binding sulphates to the choline molecule may represent a sulphate detoxification mechanism since only chloride anions, but not sulphate, are excreted through the salt glands present in members of this family [161]. Choline-O-sulphate synthesis competes with that of GB for the available choline and, therefore, it may be one of the factors involved in the evolution of alternative betaines ( $\beta$-alanine betaine and proline betaine) biosynthesis pathways from substrates other than choline [146,151].

The compound $\beta$-alanine betaine, specific of the Plumbaginaceae family, is synthesised by methylation of $\beta$-alanine, a reaction that does not require oxygen and may be regarded as an adaptation to anoxic saline environments $[146,150,151]$. In agreement with this idea, Limonium species growing in dry, sandy or rocky soils are generally GB accumulators, whereas those typical of salt marshes synthesise $\beta$-alanine betaine [159] predominantly. Proline betaine and hydroxyproline betaine accumulate at the expense of free Pro. Proline 
betaine is more efficient than Pro as osmoprotectant; for this reason, it may confer increased osmotic stress resistance to Limonium plants using this Pro derivative as a functional osmolyte [146,150,151].

In addition to these diverse metabolites, sugars and polyols have also been reported as functional osmolytes in Limonium. Gagneul et al. [143], highlighted this role for free sugars, cyclitols, and organic acids previously overlooked in this genus. These authors considered that L. latifolium, the species they analysed, behaves as a 'glycohalophyte', with a strong ability to allocate sucrose and hexoses to counteract deleterious salinity effects, and also reported on the role of chiro and mio-inositol in this species. The same compounds were also identified in L. sinuatum [156], whereas pinitol has been reported as the main osmolyte in L. gmelinii [154,155].

\section{Synthesis of Antioxidant Compounds and Activation of Antioxidant Enzymes}

Reactive oxygen species (ROS), generated as by-products of normal aerobic metabolism, include free radicals, highly reactive and unstable molecules with unpaired electrons—such as singlet oxygen and superoxide, hydroxyl and perhydroxyl radicals-as well as molecular oxygen, ozone or hydrogen peroxide, among others [36]. Under different biotic and abiotic stress conditions, including high salinity, ROS accumulate in excess, provoking oxidative stress in plants by oxidation of amino acid residues in proteins, the unsaturated fatty acids of cell membranes, and the nitrogenous bases in DNA [32,34]. Several biochemical markers can be used to assess the level of oxidative stress affecting the plants; one of them, malondialdehyde (MDA), a final product of polyunsaturated fatty acids peroxidation, is widely used as it is considered an excellent marker of oxidative stress [161]. Another approach to study how stress treatments modify the cellular redox state is based on the direct quantification of specific ROS, such as hydrogen peroxide, a stable, non-radical compound mainly produced in peroxisomes and chloroplasts [162,163]. At least theoretically, stress-induced ROS accumulation should be less pronounced in stress-tolerant than in stress-sensitive species. Therefore, when comparing the responses to salinity, or other stresses, of different related taxa, it is to be expected that higher MDA and $\mathrm{H}_{2} \mathrm{O}_{2}$ contents will be measured, under the same experimental conditions, in those more susceptible to stress.

Plants respond to oxidative stress by activating the synthesis and accumulation of antioxidant compounds and increasing antioxidant enzymes' activity. Several enzymatic systems contribute to ROS elimination and the maintenance of the appropriate cellular redox state. SOD, for example, constitutes a primary defence against ROS by catalysing the dismutation of superoxide radicals into $\mathrm{O}_{2}$ and $\mathrm{H}_{2} \mathrm{O}_{2}$ [164]. SOD specific activity is enhanced by de novo synthesis of the enzyme in the presence of its superoxide substrate, which activates the transcription of the corresponding genes [165]. $\mathrm{H}_{2} \mathrm{O}_{2}$, although not as reactive as free radicals, is still toxic, and several enzymes contribute to its elimination. The most relevant are CAT, which decomposes $\mathrm{H}_{2} \mathrm{O}_{2}$ into $\mathrm{O}_{2}$ and $\mathrm{H}_{2} \mathrm{O}$ and is induced by accumulation of its substrate [166], and APX, which catalyses the reduction of hydrogen peroxide coupled to ascorbate oxidation. GR, employing NADPH as the specific cofactor, catalyses the reduction of oxidised glutathione (GSSG) to its reduced form (GSH), thus contributing to maintaining the adequate cellular redox state [167].

Under severe and/or prolonged stress, the enzymatic antioxidant machinery may be overcome, and the second line of defence is activated by the synthesis and accumulation of non-enzymatic antioxidants [168]. Among these compounds, vitamins E and C, reduced glutathione, carotenoids and phenolic compounds, particularly the subgroup of flavonoids, have special relevance. Besides many other biological functions, these metabolites are involved in plants' responses to all types of abiotic stresses, including salinity, through reduction of oxidative stress [169].

ROS production and toxicity is common in glycophytes and halophytes. Environmental stressful conditions disrupt plant metabolic homeostasis; as a result, as indicated above, the production of ROS is drastically increased, causing oxidative stress in the cells. However, halophytes seem to be able to counteract ROS effects, maintaining them at levels 
that are not toxic, even at high external salinity $[170,171]$. For example, low lipid peroxidation, assessed by quantifying MDA contents in the plants, has been reported in several halophytes, both sampled in the field [138] or subjected to controlled salt stress treatments in the greenhouse [145]. Antioxidant enzymes have been regarded as the essential components of the adaptive defence mechanism against oxidative stress in halophytes [107]. Therefore, reports on oxidative stress in this category of plants have focused mostly on ROS enzymatic scavenging systems [172]. Several publications showed high constitutive levels in halophytes of antioxidant enzymes, such as SOD, CAT, different peroxidases or GR; the induction of new isoenzymes of some of them; and rapid activation of the enzymatic machinery before the accumulation of ROS to a level that can induce irreversible damage [171,172].

In agreement with the above data, many studies report low levels of oxidative stress in Limonium plants under natural or artificial stress conditions, maintained mostly by activation of enzymatic antioxidant systems. For example, MDA contents remained low in four Limonium species (L. girardianum, L. narbonense, L. santapolense and L. virgatum) from eastern Spain, sampled in the field in summer [17]. High temperatures and intense drought lead to the highest salinity and the lowest moisture in the soil, making summer the most stressful season under Mediterranean climate. Responses to water stress of these species were also analysed under controlled greenhouse conditions, by withholding irrigation for one month. In all cases, neither the total free radical scavenging activity of the leaf extracts nor MDA or $\mathrm{H}_{2} \mathrm{O}_{2}$ contents, differed significantly between the water-stressed and control plants, except for a slight (but statistically significant) increase in MDA levels in the leaves of $L$. narbonense [111]. Furthermore, a significant increase in the specific activity of antioxidant enzymes (SOD, CAT, APX, GR) was generally observed in response to the water deficit treatment, albeit with quantitative and qualitative differences between the four species and the four enzymes; on the contrary, no significant changes were observed in the leaf contents of antioxidant compounds [108]. Similar behaviour has been observed in other species of the genus, such as L. latifolium, in which lipid peroxidation-assessed by MDA content measurements - did not vary significantly in response to salt treatments [119], or L. bicolor, where high SOD, POD and CAT enzyme activities were shown to ensure a low level of oxidative stress [117]. Nevertheless, under specific experimental conditions, different results have also been reported; for example, an increase in $\mathrm{H}_{2} \mathrm{O}_{2}$ and MDA concentrations was detected in L. stocksii and L. deliactulum subjected to high salinity treatments [63,112].

The last species mentioned above, $L$. delicatulum, has been the subject of more extensive research. Plant growth was stimulated at moderate salt concentrations, up to $200 \mathrm{mM} \mathrm{NaCl}$, compared to the control; growth was inhibited only by higher concentrations, which generated a significant increase in $\mathrm{H}_{2} \mathrm{O}_{2}$ and MDA levels. The antioxidant activity in this species is based mainly on the activation of antioxidant enzymes, SOD, APX and GPX, which increased in parallel to the salt concentration applied, whereas CAT was activated only at higher concentration. However, a low correlation was established with non-enzymatic antioxidants, such as total phenolic compounds and antioxidant flavonoids [115]. Field studies were also performed on the sabkha biotype of the same species. In plants sampled from natural environments, natural fluctuations in salinity and aridity were correlated with increased concentrations of MDA and $\mathrm{H}_{2} \mathrm{O}_{2}$, and a sharp increase of polyphenols, flavonoids, flavonols, and vitamins $\mathrm{C}$ and $\mathrm{E}$. Regarding the antioxidant enzymes, SOD, GPX and APX showed enhanced activity and overexpression; as well as CAT but only when salinity was maximal in summer [173].

Finally, a study on eight Limonium species from stressful habitats in Tunisia indicated that the synthesis of secondary metabolites is enhanced with the severity of environmental conditions, especially salinity and drought. Limonium vulgare contained the highest concentrations of flavonoids, flavonols, vitamin C, vitamin E and carotenoids, and showed the highest SOD, GPX, APX and CAT activities. Enzymatic activities increased during the period when the biotopes' salinity was high [62]. 
Most studies on antioxidants in Limonium, like those described in the previous paragraphs, reveal the contribution of antioxidant enzymatic systems to the plants responses to abiotic stress. However, as other halophytes that possess efficient mechanisms of tolerance based on the control of ion transport and accumulation of osmoprotectants, Limonium may not require a high level of antioxidant activity simply because excessive ROS accumulation is prevented by those mechanisms, limiting the generation of oxidative stress [172]. Besides the salt glands and the accumulation of toxic ions in the foliar tissue vacuoles, many Limonium species have high constitutive concentrations of glycine betaine or polyols, which act as ROS scavengers, in addition to their role in osmotic adjustment [172]. Therefore, increased antioxidant activity should be treated as a damage control mechanism rather than a trait directly conferring salinity stress tolerance' [172].

\section{Conclusions}

Limonium species, most highly resistant to elevated salinity and many also to drought, constitute attractive models for fundamental research on plant responses to abiotic stress and their tolerance mechanisms. They include morpho-anatomical adaptations, such as salt glands, typical of recretohalophytes; the control of ion transport to accumulate toxic $\mathrm{Na}^{+}$(and $\mathrm{Cl}^{-}$) in the leaf vacuoles-with the concomitant synthesis of a wide variety of osmolytes for osmotic adjustment under stress-and with additional roles as osmoprotectants; or the activation of efficient antioxidant systems. The genus includes numerous endemics, especially in the Mediterranean area, with high intrinsic conservation value as rare and threatened species, but also due to their presence in European priority habitats. From a practical point of view, species of this genus have a great potential for the development, through appropriated breeding programmes, of (minor) commercial crops of ornamental, medicinal and gourmet food plants; and also, plants to be used in phytoremediation actions for decontamination of heavy metal-polluted soils. In this way, the enormous genetic diversity and high stress tolerance of wild Limonium taxa could be efficiently utilised to obtain plants to be cultivated under harsh conditions of salinity and drought, tolerating limited irrigation and/or irrigation with brackish waters. They would contribute to a sustainable, 'saline' or 'arid' agriculture, without competing with conventional crops for limited resources, such as fertile land and high-quality water for irrigation.

Author Contributions: Conceptualization, M.B. and O.V.; resources, M.-N.G., M.B.; data curation, S.G.-O.; writing—original draft preparation, S.G.-O. and M.-N.G.; writing—review and editing, M.B. and O.V.; visualisation, S.G.-O. and M.-N.G.; supervision, O.V.; project administration, M.B.; funding acquisition, M.B. All authors have read and agreed to the published version of the manuscript.

Funding: Work in the authors' laboratories was funded by Generalitat Valenciana, grant AICO/2017/039.

Conflicts of Interest: The authors declare no conflict of interest.

\section{References}

1. Erben, M. Die Gattung Limonium im südwestmediterranen Raum. Mitt. Bot. Staatssamml. München. 1978, 14, 361-631.

2. Koutroumpa, K.; Theodoridis, S.; Warren, B.H.; Jiménez, A.; Celep, F.; Doğan, M.; Romeiras, M.M.; Santos-Guerra, A.; FernándezPalacios, J.M.; Caujapé-Castells, J.; et al. An expanded molecular phylogeny of Plumbaginaceae, with emphasis on Limonium (sea lavenders): Taxonomic implications and biogeographic considerations. Ecol. Evol. 2018, 1-8. [CrossRef]

3. Buira, A.; Aedo, C.; Medina, L. Spatial patterns of the Iberian and Balearic endemic vascular flora. Biodivers. Conserv. 2017, 26, 479-508. [CrossRef]

4. The IUCN National Red List Working Group (NRLWG). IUCN/NRLWG National Red List Database. Available online: https: //www.nationalredlist.org/ (accessed on 20 April 2020).

5. Laguna, E.; Fos, S.; Ferrando-Pardo, I.; Ferrer-Gallego, P.P. Endangered halophytes and their conservations: Lessons from Eastern Spain. In From Molecules to Ecosystems towards Biosaline Agriculture; Grigore, M.N., Ed.; Springer: Cham, Switzerland; Heidelberg, Germany, 2020; pp. 1-64.

6. European Commission. Council Directive 92/43 CEE on the Conservation of Natural Habitats and of Wild Fauna and Flora. OJL 1992, 206, 1-50.

7. European Commission DG Environment. Interpretation Manual of European Union Habitats (Version EUR27); European Commission DG Environment: Brussels, Belgium, 2007. 
8. $\quad$ Ferrer-Gallego, P.P.; Navarro, A.; Pérez-Rovira, P.; Roselló, R.; Rosselló, J.A.; Rosato, M.; Laguna, E. A new polyploid species of Limonium (Plumbaginaceae) from the Western Mediterranean basin. Phytotaxa 2015, 234, 263-270. [CrossRef]

9. Palacios, C.; Rosselló, J.A.; González-Candelas, F. Study of the evolutionary relationships among Limonium species (Plumbaginaceae) using nuclear and cytoplasmic molecular markers. Mol. Phylogen. Evol. 2000, 14, 232-249. [CrossRef] [PubMed]

10. Boissier, E. Plumbaginaceae. In Prodromus Systematis Naturalis Regni Vegetabilis; de Candolle, A.P., Ed.; Treuttel et Wurz: Paris, France, 1848; pp. 617-696.

11. Boissier, E. Diagnoses Plantarum Orientalium Novarum; Baillière: Paris, France, 1859; pp. 61-71.

12. Akhani, H.; Malekmohammadi, M.; Mahdavi, P.; Gharibiyan, A.; Chase, M.W. Phylogenetics of the Irano-Turanian taxa of Limonium (Plumbaginaceae) based on ITS nrDNA sequences and leaf anatomy provides evidence for species delimitation and relationships of lineages. Bot. J. Linn. Soc. 2013, 171, 519-550. [CrossRef]

13. Lledó, M.D.; Crespo, M.B.; Fay, M.F.; Chase, M.W. Molecular phylogenetics of Limonium and related genera (Plumbaginaceae): Biogeographical and systematic implications. Am. J. Bot. 2005, 92, 1189-1198. [CrossRef] [PubMed]

14. Malekmohammadi, M.; Akhani, H.; Borsch, T. Phylogenetic relationships of Limonium (Plumbaginaceae) inferred from multiple chloroplast and nuclear loci. Taxon 2017, 66, 1128-1146. [CrossRef]

15. Erben, M. Limonium Mill. In Flora Ibérica; Castroviejo, S., Aedo, C., Cirujano, S., Laínz, M., Montserrat, P., Morales, R., Muñoz Garmendia, F., Navarro, C., Paiva, J., Eds.; Editorial CSIC: Madrid, Spain, 1993; Volume 3, pp. 2-143.

16. Al Hassan, M.; Estrelles, E.; Soriano, P.; López-Gresa, M.P.; Bellés, J.M.; Boscaiu, M.; Vicente, O. Unraveling salt tolerance mechanisms in halophytes: A comparative study on four Mediterranean Limonium species with different geographic distribution patterns. Front. Plant. Sci. 2017, 17, 1438. [CrossRef] [PubMed]

17. González-Orenga, S.; Llinares, J.V.; Al Hassan, M.; Fita, A.; Collado, F.; Lisón, P.; Vicente, O.; Boscaiu, M. Physiological and morphological characterisation of Limonium species in their natural habitats: Insights into their abiotic stress responses. Plant Soil. 2020, 449, 267-284. [CrossRef]

18. Yuan, F.; Leng, B.; Wang, B. Progress in studying salt secretion from the salt glands in recretohalophytes: How do plants secrete salt? Front. Plant Sci. 2016, 7, 977. [CrossRef]

19. Shabala, S.; Bose, Y.; Hedrich, R. Salt bladders: Do they matter? Trends Plant Sci. 2014, 19, 687-691. [CrossRef] [PubMed]

20. Yuan, F.; Lyv, M.J.; Leng, B.Y.; Zheng, G.Y.; Feng, Z.T.; Li, P.H.; Wang, B.S. Comparative transcriptome analysis of developmental stages of the Limonium bicolor leaf generates insights into salt gland differentiation. Plant Cell. Environ. 2015, 38, 1637-1657. [CrossRef]

21. Lipschitz, N.; Waisel, Y. Existence of salt glands in various genera of the Gramineae. New Phytol. 1974, 73, 507-513. [CrossRef]

22. Zhang, D.Y.; Yin, L.K.; Pan, B.R. A review on the study of salt glands of Tamarix. Acta Bot. Bor. Occid. Sin 2003, $23,190-194$.

23. Grigore, M.N.; Toma, C. Anatomical Adaptations of Halophytes. A Review of Classic Literature and Recent Findings; Springer: Cham, Switzerland, 2017.

24. Flowers, T.J.; Colmer, T.D. Salinity tolerance in halophytes. New. Phytol. 2008, 179, 945-963. [CrossRef] [PubMed]

25. Munns, R.; Tester, M. Mechanisms of salinity tolerance. Annu. Rev. Plant Biol. 2008, 59, 651-681. [CrossRef] [PubMed]

26. Türkan, I.; Demiral, T. Recent developments in understanding salinity tolerance. Environ. Exp. Bot. 2009, 67, 2-9. [CrossRef]

27. Szabados, L.; Savouré, A. Proline: A multifunctional amino acid. Trends Plant Sci. 2010, 15, 89-97. [CrossRef]

28. Slama, I.; Abdelly, C.; Bouchereau, A.; Flowers, T.; Savouré, A. Diversity, distribution and roles of osmoprotective compounds accumulated in halophytes under abiotic stress. Ann. Bot. 2015, 115, 433-447. [CrossRef] [PubMed]

29. Raven, J.A. Regulation of $\mathrm{pH}$ and generation of osmolarity in vascular plants: A cost-benefit analysis in relation to efficiency of use of energy, nitrogen and water. New Phytol. 1985, 101, 25-77. [CrossRef]

30. Shabala, S.; Shabala, L. Ion transport and osmotic adjustment in plants and bacteria. Biomol. Concepts 2011, 2, 407-419. [CrossRef]

31. Wyn Jones, R.; Storey, R.; Leigh, R.A.; Ahmad, N.; Pollard, A. A hypothesis on cytoplasmic osmoregulation. In Regulation of Cell membrane Activities in Plants; Marre, E., Ciferri, O., Eds.; Elsevier: Amsterdam, The Netherlands, 1977; pp. 121-136.

32. Yeo, A.R. Salinity resistance: Physiologies and prices. Physiol. Plant. 1983, 58, 214-222. [CrossRef]

33. Glenn, E.P.; Brown, J.J.; Blumwald, E. Salt tolerance and crop potential of halophytes. Crit. Rev. Plant Sci. 1999, 18, 227-255. [CrossRef]

34. Sharma, P.; Jha, A.B.; Dubey, R.S.; Pessarakli, M. Reactive oxygen species, oxidative damage, and antioxidative defense mechanism in plants under stressful conditions. J. Bot. 2012, 217037. [CrossRef]

35. Golldack, D.; Li, C.; Harikrishnan, M.; Probst, N. Tolerance to drought and salt stress in plants: Unraveling the signaling networks Front. Plant Sci. 2014, 5, 151. [CrossRef]

36. Apel, K.; Hirt, H. Reactive oxygen species: Metabolism, oxidative stress, and signal transduction. Annu. Rev. Plant. Biol. 2004, 55, 373-399. [CrossRef]

37. Vicente, O.; Boscaiu, M.; Naranjo, M.A.; Estrelles, E.; Bellés, J.M.; Soriano, P. Responses to salt stress in the halophyte Plantago crassifolia (Plantaginaceae). J. Arid Environ. 2004, 58, 463-481. [CrossRef]

38. Ungar, I.A. Ecophysiology of Vascular Halophytes; CRC: Boca Raton, FL, USA, 1991.

39. Chapman, V.J. Salt Marshes and Salt Deserts of the World. Ecol. Halophytes 1974, 79, 3-19.

40. Sağlam, C.; Önder, S. The use of native halophytes in landscape design in The Central Anatolia, Turkey. Turk. J. Agric. Food Sci. Technol. 2018, 6, 1718-1726. [CrossRef] 
41. García-Caparrós, P.; Llanderal, A.; Lao, M.T. Halophytes as an option for the restoration of degraded areas and landscaping. In Handbook of Halophytes, From Molecules to Ecosystems towards Biosaline Agriculture; Grigore, M.N., Ed.; Springer: Cham, Switzerland, 2020. [CrossRef]

42. Ksouri, R.; Megdiche, W.; Debez, A.; Falleh, H.; Grignon, C.; Abdelly, C. Salinity effects on polyphenol content and antioxidant activities in leaves of the halophyte Cakile maritima. Plant Physiol. Biochem. 2007, 45, 244-249. [CrossRef] [PubMed]

43. Ksouri, R.; Megdiche, W.; Falleh, H.; Trabelsi, N.; Boulaaba, M.; Smaoui, A.; Abdelly, C. Influence of biological, environmental and technical factors on phenolic content and antioxidant activities of Tunisian halophytes. Comptes Rendus Biol. 2008, 331, 865-873. [CrossRef]

44. Yang, M.H.; Kim, N.H.; Heo, J.D.; Sung, S.H.; Jeong, E.J. Hepatoprotective effects of Limonium tetragonum, edible medicinal halophyte growing near seashores. Pharmacogn. Mag. 2014, 10, 563-568. [CrossRef]

45. Cervelli, C.; Farina, E.; Dalla Guda, C.; Giovannini, A.; Liotta, A.; Paterniani, T.; Burchi, G.; Cacini, S.; Antonetti, M.; Zizzo, G.; et al. Development of new ornamental plants and germplasm selection in Mediterranean native species. Acta Hortic. 2012, 937, 45-50. [CrossRef]

46. Burchi, G.; Mercuri, A. Results of a breeding activity on Limonium ssp. Acta Hort. 2006, 714, 43-50. [CrossRef]

47. Kaninski, A.I.; Ivanova, I.; Bistrichanov, S.; Zapryanova, N.; Atanassova, B.; Iakimova, E.T. Ex situ conservation of endangered Limonium species in the Bulgarian flora. J. Fruit Ornam. Plant Res. 2012, 20, 115-129. [CrossRef]

48. Lin, L.-C.; Chou, C.J. Flavonoids and phenolics from Limonium sinense. Planta Med. 2000, 66, 382-383. [CrossRef]

49. Geng, D.; Chi, X.; Dong, Q.; Hu, F. Antioxidants screening in Limonium aureum by optimised online HPLC-DPPH assay. Ind. Crops Prod. 2015, 67, 492-497. [CrossRef]

50. Corrêa, R.C.G.; Di Gioia, F.; Ferreira, I.C.F.R.; Petropoulos, S.A. Halophytes for future horticulture. In Handbook of Halophytes. From Molecules to Ecosystems towards Biosaline Agriculture; Grigore, M.N., Ed.; Springer: Cham, Switzerland, 2020. [CrossRef]

51. Medini, F.; Bourgou, S.; Lalancette, K.; Snoussi, M.; Mkadmini, K.; Coté, I.; Ksouri, R. Phytochemical analysis, antioxidant, anti-inflammatory, and anticancer activities of the halophyte Limonium densiflorum extracts on human cell lines and murine macrophages. S. Afr. J. Bot. 2015, 99, 158-164. [CrossRef]

52. Blainski, A.; Gionco, B.; Oliveira, A.G.; Andrade, G.; Scarminio, I.S.; Silva, D.B.; Lopes, N.P.; Mello, J.C.P. Antibacterial activity of Limonium brasiliense (Baicuru) against multidrug-resistant bacteria using a statistical mixture design. J. Ethnopharmacol. 2017, 198, 313-323. [CrossRef] [PubMed]

53. Medini, F.; Legault, J.; Pichette, A.; Abdelly, C.; Ksouri, R. Antiviral efficacy of Limonium densiflorum against HSV-1 and influenza viruses. S. Afr. J. Bot. 2014, 92, 65-72. [CrossRef]

54. Aniya, Y.; Miyagi, C.; Nakandakari, A.; Kamiya, S.; Imaizumi, N.; Ichiba, T. Free radical scavenging action of the medicinal herb Limonium wrightii from the Okinawa islands. Phytomedicine 2002, 9, 239-244. [CrossRef]

55. Murray, A.P.; Rodriguez, S.; Frontera, M.A.; Tomas, M.A.; Mulet, M.C. Antioxidant metabolites from Limonium brasiliense (boiss.) Kuntze. Z. Naturforsch. C 2004, 59, 477-480. [CrossRef]

56. Medini, F.; Ksouri, R.; Falleh, H.; Megdiche, W.; Trabelsi, N.; Abdelly, A.C. Effects of physiological stage and solvent on polyphenol composition, antioxidant and antimicrobial activities of Limonium densiflorum. J. Med. Plants Res. 2011, 5, 6719-6730.

57. Rodrigues, M.J.; Soszynski, A.A.; Martins, A.; Rauter, A.P.; Neng, N.R.; Nogueira, J.M.F.; Varela, J.; Barreira, L.; Custódio, L. Unravelling the antioxidant potential and the phenolic composition of different anatomical organs of the marine halophyte Limonium algarvense. Ind. Crops Prod. 2015, 77, 315-322. [CrossRef]

58. Trabelsi, N.; Oueslati, S.; Falleh, H.; Waffo-Téguo, P.; Papastamoulis, Y.; Merillon, J.M.; Abdelly, C.; Riadh, K. Isolation of powerful antioxidants from the medicinal halophyte Limoniastrum guyonianum. Food Chem. 2012, 135, 1419-1424. [CrossRef]

59. Ruiz-Riaguas, A.; Zengin, G.; Sinan, K.I.; Salazar-Mendías, C.; Llorent-Martínez, E.J. Phenolic profile, antioxidant activity, and enzyme inhibitory properties of Limonium delicatulum (Girard) Kuntze and Limonium quesadense Erben. J. Chem. 2020, 1016208. [CrossRef]

60. Rodrigues, M.J.; Neves, V.; Martins, A.; Rauter, A.P.; Neng, N.R.; Nogueira, J.M.F.; Varela, J.; Barreira, L.; Custódio, L. In vitro antioxidant and anti-inflammatory properties of Limonium algarvense flowers' infusions and decoctions: A comparison with green tea (Camellia sinensis). Food Chem. 2016, 200, 322-329. [CrossRef]

61. Kim, N.H.; Heo, J.D.; Rho, J.R.; Yang, M.H.; Jeong, E.J. Anti-obesity effect of halophyte crop, Limonium tetragonum in high-fat diet-induced obese mice and 3T3-L1 adipocytes. Biol. Pharm. Bull. 2017, 40, 1856-1865. [CrossRef]

62. Souid, A.; Bellani, L.; Gabriele, M.; Pucci, L.; Smaoui, A.; Abdelly, C.; Hamed, K.B.; Longo, V. Phytochemical and biological activities in Limonium species collected in different biotopes of Tunisia. Chem. Biodivers. 2019, 16, e1900216. [CrossRef] [PubMed]

63. Zia, S.; Khan, M.A. Effect of light, salinity, and temperature on seed germination of Limonium stocksii. Can. J. Bot. 2004, 82, 151-157. [CrossRef]

64. El-Amier, Y.A.; Ejgholi, A.A. Fodder potentialities of three naturally growing in Egypt. J. Environ. Sci. 2014, 43, 647-662.

65. Manousaki, E.; Kalogerakis, N. Halophytes-An Emerging Trend in Phytoremediation. Int. J. Phytoremed. 2011, 13, 959-969. [CrossRef]

66. Manousaki, E.; Galanaki, K.; Papadimitriou, L.; Kalogerakis, N. Metal phytoremediation by the halophyte Limoniastrum monopetalum (L.) Boiss: Two contrasting ecotypes. Int. J. Phytoremed. 2014, 16, 755-769. [CrossRef]

67. Hasanuzzaman, M.; Nahar, K.; Alam, M.M.; Bhowmik, P.C.; Hossain, M.A.; Rahman, M.M.; Prasad, M.N.; Ozturk, M.; Fujita, M. Potential use of halophytes to remediate saline soils. BioMed Res. Int. 2014, 589341. [CrossRef] 
68. Saddhe, A.A.; Manuka, R.; Nikalje, G.C.; Penna, S. Halophytes as a potential resource for phytodesalination. In Handbook of Halophytes, From Molecules to Ecosystems towards Biosaline Agriculture; Grigore, M.N., Ed.; Springer: Cham, Switzerland, 2020. [CrossRef]

69. Perrino, E.V.; Musarella, C.M.; Magazzini, P. Management of grazing Italian river buffalo to preserve habitats defined by Directive 92/43/EEC in a protected wetland area on the Mediterranean coast: Palude Frattarolo, Apulia, Italy. Euro-Mediterr. J. Environ. Integr. 2020. [CrossRef]

70. Martínez Sánchez, M.J.; García Lorenzo, M.L.; Pérez Sirvent, C.; Bech, J. Trace element accumulation in plants from an aridic area affected by mining activities. J. Geochem. Explor. 2012, 123, 8-12. [CrossRef]

71. Sheikh-Assadi, M.; Khandan-Mirkohi, A.; Alemardan, A.; Moreno-Jiménez, E. Mycorrhizal Limonium sinuatum (L.) Mill. Enhances accumulation of lead and cadmium. Int. J. Phytoremed. 2015, 17, 556-562. [CrossRef]

72. Grigore, M.N.; Toma, C. Morphological and anatomical adaptations of halophytes: A review. In Handbook of Halophytes, From Molecules to Ecosystems towards Biosaline Agriculture; Grigore, M.N., Ed.; Springer: Cham, Switzerland, 2020. [CrossRef]

73. Grigore, M.N.; Toma, C. Structure of salt glands of Plumbaginaceae. Rediscovering old findings from 19th century. 'Mettenius' or 'Licopoli' organs? J. Plant Dev. 2016, 23, 37-52.

74. Grigore, M.N.; Toma, C. Integrative anatomy of halophytes from Mediterranean climate. In Handbook of Halophytes, From Molecules to Ecosystems towards Biosaline Agriculture; Grigore, M.N., Ed.; Springer: Cham, Switzerland, 2020. [CrossRef]

75. Răvăruț, M. Plumbaginaceae. In Flora Republicii Populare Romîne; Săvulescu, T., Ed.; Editura Acdemiei Republicii Populare Romîne: Bucuresti, Romania, 1960; Volume 7, pp. 21-40.

76. Linchevskii, L.A. Plumbaginaceae. In Flora of the U.S.S.R. (Series initiated by V. L. Komarov); Shishkin, B.K., Bobrov, E.G., Eds.; Translated from Russian; Israel Program for Scientific Translations: Jerusalem, Israel, 1967; pp. 216-348.

77. Antonelli-Ushirobira, T.M.; Blainski, A.; Gancedo, N.C.; Gaburo, F.; Cardoso, K.A.K.; Leite-Melo, E.V.S.; Mello, J.C.P.; de Milaneze-Gutierre, M.A. Morpho-anatomical study of rhizome of Limonium brasiliense. Rev. Bras. Farmacogn. 2015, 25, 320-327. [CrossRef]

78. Grigore, M.N.; Ivănescu, L.; Toma, C. Halophytes. An Integrative Anatomical Study; Springer: Cham, Switzerland, 2014.

79. Moțiu, T.; Toma, C.; Tiron, A.; Niță, M. Contribuții la cunoașterea structurii organelor vegetative de Limonium gmelini (Willd). Biol. Veget. 1987, 3, 11-14.

80. Solereder, H. Systematic Anatomy of the Dicotyledons. A Handbook for Laboratories of Pure and Applied Botany; Clarendon: Oxford, UK, 1908; Volume 2.

81. Colombo, P.; Trapani, S. Morpho-anatomical observations on three Limonium species endemic to the Pelagic Islands. Fl. Medit. 1992, 2, 77-90.

82. Zoric, L.; Milic, D.; Karanovic, D.; Lukovic, J. Anatomical adaptations of halophytes within the Southern Pannonian Plain Region. In Handbook of Halophytes, From Molecules to Ecosystems towards Biosaline Agriculture; Grigore, M.N., Ed.; Springer: Cham, Switzerland, 2020. [CrossRef]

83. Zoric, L.; Anackov, G.T.; Karanovic, D.; Lukovic, J. Leaf structural adaptations of two Limonium Miller (Plumbaginales, Plumbaginaceae) taxa. J. Nat. Sci. Matica Srpska Novi Sad 2013, 125, 43-54. [CrossRef]

84. De Fraine, E. The morphology and anatomy of the genus Statice as represented at Blakeney Point. I. Statice binervosa G.E. Smith and Statice bellidifolia D.C. (=Statice reticulata). Ann. Bot. 1916, 30, 239-282. [CrossRef]

85. Grigore, M.N.; Toma, C. Structuri Secretoare de Săruri la Halofite. O Abordare Integrativă; Academiei Române: Bucuresti, Romania, 2010.

86. Yuan, F.; Wang, B. Adaptation of Recretohalophytes to Salinity. In Handbook of Halophytes, From Molecules to Ecosystems towards Biosaline Agriculture; Grigore, M.N., Ed.; Springer: Cham, Switzerland, 2020. [CrossRef]

87. Caperta, A.D.; Róis, A.S.; Teixeira, G.; Garcia-Caparros, P.; Flowers, T.J. Secretory structures in plants: Lessons from the Plumbaginaceae on their origin, evolution and roles in stress tolerance. Plant. Cell. Environ. 2020, 43, 2912-2931. [CrossRef]

88. Grigore, M.N.; Flowers, T.J. Evolution in angiosperm halophytes. In Handbook of Halophytes, From Molecules to Ecosystems towards Biosaline Agriculture; Grigore, M.N., Ed.; Springer: Cham, Switzerland, 2021. [CrossRef]

89. Gul, B.; Ansari, R.; Flowers, T.; Khan, M.A. Germination strategies of halophyte seeds under salinity. Environ. Exp. Bot. 2013, 92, 4-18. [CrossRef]

90. Kazachkova, Y.; Khan, A.; Acuña, T.; López-Díaz, I.; Carrera, E.; Khozin-Goldberg, I.; Fait, A.; Barak, S. Salt induces features of a dormancy like state in seeds of Eutrema (Thellungiella) salsugineum, a halophytic relative of Arabidopsis. Front. Plant Sci. 2016, 7, 1071. [CrossRef]

91. Khan, M.A.; Gul, B. Halophyte seed germination. In Ecophysiology of High Salinity Tolerant Plants; Khan, M., Weber, D., Eds.; Springer: Dordrecht, The Netherlands, 2006; pp. 11-30.

92. Khan, M.A. Comparative influence of salinity and temperature on the germination of subtropical halophytes. In Halophyte Uses in Different Climates I: Ecological and Ecophysiological Studies. Progress in Biometeriology; Lieth, H., Moschenko, M., Lohman, M., Koyro, H.W., Hamdy, A., Eds.; Backhuys Publishers: Leiden, The Netherlands, 1999; pp. 77-88.

93. Ungar, I.A. Seed germination and seed-bank ecology of halophytes. In Seed Development and Germination; Kigel, J., Galili, G., Eds.; Marcel and Dekker Inc.: New York, NY, USA, 1995.

94. Giménez Luque, E.; Delgado-Fernández, I.; Gómez Mercado, F. Effect of salinity and temperature on seed germination in Limonium cossonianum. Botany 2013, 91, 12-16. [CrossRef] 
95. Delgado Fernández, I.C.; Giménez Luque, E.; Gómez Mercado, F.; Marrrero, J.M. Germination responses of Limonium insigne (Coss.) Kuntze to salinity and temperature. Pak. J. Bot. 2015, 47, 807-812.

96. Delgado Fernández, I.C.; Giménez Luque, E.; Gómez Mercado, F.; Pedrosa, V. Influence of temperature and salinity on the germination of Limonium tabernense Erben from Tabernas Desert (Almería, SE Spain). Flora 2016, 218, 68-74. [CrossRef]

97. Fos, M.; Alfonso, L.; Ferrer-Gallego, P.P.; Laguna, E. Effect of salinity, temperature and hypersaline conditions on the seed germination in Limonium mansanetianum an endemic and threatened Mediterranean species. Plant Biosyst. 2020, 155, 165-171. [CrossRef]

98. Melendo, M.; Giménez, E. Seed germination responses to salinity and temperature in Limonium supinum (Plumbaginaceae), an endemic halophyte from Iberian Peninsula. Plant Biosyst. 2019, 153, 257-263. [CrossRef]

99. González-Orenga, S.; Ferrer-Gallego, P.P.; Laguna, E.; López-Gresa, M.P.; Donat-Torres, M.P.; Verdeguer, M.; Vicente, O.; Boscaiu, M. Insights on salt tolerance of two endemic Limonium species from Spain. Metabolites 2019, 9, 294. [CrossRef]

100. Redondo-Gómez, S.; Mateos Naranjo, E.; Garzón, O.; Castillo, J.M.; Luque, T.; Figueroa, M.E. Effects of salinity on germination and seedling establishment of endangered Limonium emarginatum (Willd.) O. Kuntze. J. Coast. Res. 2008, 24, 201-205. [CrossRef]

101. Monllor, M.; Soriano, P.; Llinares, J.V.; Boscaiu, M.; Estrelles, E. Assessing effects of temperature change on four Limonium species from threatened Mediterranean salt-affected habitats. Not. Bot. Horti Agrob. 2018, 46, 286-291. [CrossRef]

102. Yildiz, M.; Cenkci, S.; Kargioglu, M. Effects of salinity, temperature, and light on seed germination in two Turkish endemic halophytes, Limonium iconicum and L. lilacinum (Plumbaginaceae). Seed Sci. Technol. 2008, 36, 646-656. [CrossRef]

103. Kleemann, S.G.L.; Gill, G. Seed germination and seedling recruitment behavior of winged sea lavender (Limonium lobatum) in Southern Australia. Weed Sci. 2018, 66, 485-493. [CrossRef]

104. Mahmoud, A.; El Sheikh, A.M.; Abdul Baset, S. Germination of two halophytes: Halopeplis perfoliata and Limonium axillare from Saudi Arabia. J. Arid Environ. 1983, 6, 87-98. [CrossRef]

105. Woodell, S.R.J. Salinity and seed germination patterns in coastal plants. Vegetation 1985, 61, 223-229. [CrossRef]

106. Ungar, I.A. Influence of salinity on seed germination in succulent halophytes. Ecology 1962, 3, 329-335. [CrossRef]

107. Ungar, I.A. Influence of salinity and temperature on seed germination. Ohio J. Sci. 1967, 67, 120-123.

108. Yuan, F.; Guo, J.; Shabala, S.; Wang, B. Reproductive physiology of halophytes: Current standing. Front. Plant Sci. 2019, 9, 1954. [CrossRef]

109. Flowers, T.J.; Hajibagheri, M.A.; Clipson, N.J.W. Halophytes. Q. Rev. Biol. 1986, 61, 313-335. [CrossRef]

110. Al Hassan, M.; Morosan, M.; López-Gresa, M.D.P.; Prohens, J.; Vicente, O.; Boscaiu, M. Salinity-induced aariation in biochemical markers provides insight into the mechanisms of salt tolerance in common (Phaseolus vulgaris) and runner (P. coccineus) beans. Int. J. Mol. Sci. 2016, 17, 1582. [CrossRef]

111. González-Orenga, S.; Al Hassan, M.; Llinares, J.V.; Lisón, P.; López-Gresa, M.P.; Verdeguer, M.; Vicente, O.; Boscaiu, M. Qualitative and quantitative differences in osmolytes accumulation and antioxidant activities in response to water deficit in four Mediterranean Limonium species. Plants 2019, 8, 506. [CrossRef]

112. Hameed, A.; Gulzar, S.; Aziz, I.; Hussain, T.; Gul, B.; Khan, M.A. Effects of salinity and ascorbic acid on growth, water status and antioxidant system in a perennial halophyte. AoB Plants 2015, 7, plv004. [CrossRef] [PubMed]

113. Ding, F.; Song, J.; Ruan, Y.; Wang, B.S. Comparison of the effects of $\mathrm{NaCl}$ and $\mathrm{KCl}$ at the roots on seedling growth, cell death and the size, frequency and secretion rate of salt glands in leaves of Limonium sinense. Acta Physiol. Plant. 2009, 31, 343-350. [CrossRef]

114. Morales, M.A.; Olmos, E.; Torrecillas, A.; Sánchez-Blanco, M.J.; Alarcon, J.J. Differences in water relations, leaf ion accumulation and excretion rates between cultivated and wild species of Limonium sp. grown in conditions of saline stress. Flora 2001, 196, 345-352. [CrossRef]

115. Souid, A.; Gabriele, M.; Longo, V.; Pucci, L.; Bellani, L.; Smaoui, A.; Abdelly, C.; Hamed, K. Salt tolerance of the halophyte Limonium delicatulum is more associated with antioxidant enzyme activities than phenolic compounds. Function. Plant Biol. 2016, 43, 607-619. [CrossRef]

116. Grieve, C.M.; Poss, J.A.; Grattam, S.R.; Sheuse, P.J.; Lieth, J.H.; Zeng, L. Productivity and mineral nutrition of Limonium species irrigated with saline wastewaters. Hort. Sci. 2005, 40, 654-658. [CrossRef]

117. Li, Y. Kinetics of the antioxidant response to salinity in the halophyte Limonium bicolor. Plant Soil Environ. 2008, 54, 493-497. [CrossRef]

118. Xianzhao, L.; Chunzhi, W.; Qing, S. Screening for salt tolerance in eight halophyte species from Yellow River Delta at the two initial growth stages. ISRN Agronomy 2013. [CrossRef]

119. Hamed, K.B.; Chibani, F.; Abdelly, C.; Magne, C. Growth, sodium uptake and antioxidant responses of coastal plants differing in their ecological status under increasing salinity. Biologia 2014, 69, 193-201. [CrossRef]

120. Flowers, T.J. Salt tolerance in Suaeda maritima (L.) Dum: The effect of sodium chloride on growth, respiration, and soluble enzymes in a comparative study with Pisum sativum. J. Exp. Bot. 1972, 23, 310-321. [CrossRef]

121. Khan, M.A.; Ungar, I.A.; Showalter, A.M. The effect of salinity on the growth, water status, and ion content of a leaf succulent perennial halophyte, Suaeda fruticosa (L.) Forssk. J. Arid Environ. 2000, 45, 73-84. [CrossRef]

122. Hameed, A.; Hussain, T.; Gulzar, S.; Aziz, I.; Gul, B.; Khan, M. Salt tolerance of a cash crop halophyte Suaeda fruticosa: Biochemical responses to salt and exogenous chemical treatments. Acta Physiol. Plant. 2012, 34, 2331-2340. [CrossRef]

123. Tabot, P.T.; Adams, J.B. Salt secretion, proline accumulation and increased branching confer tolerance to drought and salinity in the endemic halophyte Limonium linifolium. S. Afr. J. Bot. 2014, 94, 64-73. [CrossRef] 
124. Leng, B.Y.; Yuan, F.; Dong, X.X.; Wang, J.; Wang, B.S. Distribution pattern and salt excretion rate of salt glands in two recretohalophyte species of Limonium (Plumbaginaceae). S. Afr. J. Bot. 2018, 115, 74-80. [CrossRef]

125. Ramadan, T. Ecophysiology of salt excretion in the xerohalophyte Reaumuria hirtella. New Phytol. 1998, 139, 273-281. [CrossRef]

126. Hill, A.E. Ion and water transport in Limonium: I. Active transport by the leaf gland cells. Biochim. Biophys. Acta (BBA) Biomembr. 1967, 135, 454-460. [CrossRef]

127. Zia, S.; Egan, T.; Khan, M. Growth and selective ion transport of Limonium stocksii (Plumbaginaceae) under saline conditions. Pak. J. Bot. 2008, 40, 697-709.

128. Wang, S.; Changgui, W.; Yanrong, W.; Chen, H.; Zhou, Z.; Fu, H.; Sosebee, R.E. The characteristics of Na+, K+ and free proline distribution in several drought resistant plants of the Alxa Desert, China. J. Arid Environ. 2004, 56, 525-539. [CrossRef]

129. Lv, S.; Jiang, P.; Chen, X.; Fan, P.; Wang, X.; Li, Y. Multiple compartmentalisation of sodium conferred salt tolerance in Salicornia europaea. Plant Physiol. Biochem. 2012, 51, 47-52. [CrossRef] [PubMed]

130. Borsai, O.; Hassan, M.A.; Negrușier, C.; Raigón, M.D.; Boscaiu, M.; Sestraș, R.E.; Vicente, O. Responses to salt stress in Portulaca: Insight into its tolerance mechanisms. Plants 2020, 9, 1660. [CrossRef] [PubMed]

131. Tester, M.; Davenport, $\mathrm{R} . \mathrm{Na}^{+}$tolerance and $\mathrm{Na}^{+}$transport in higher plants. Ann. Bot. 2003, 91, 503-527. [CrossRef]

132. Alarcon, J.J.; Morales, M.A.; Torrecillas, A.; Sanchez-Blango, M.J. Growth, water relations and accumulation of organic and inorganic solutes in the halophytes Limonium latifolium cv. avignon and its interspecific hybrid Limonium caspia X Limonium latifolium cv. bettlaard during salt stress. J. Plant Physiol. 1999, 154, 795-801. [CrossRef]

133. Flowers, T.J.; Yeo, A.R. Ion relation of salt tolerance. In Solute Transport in Plant Cells and Tissues; Baker, D.A., Hall, J.L., Eds.; Longman Scientific and Technical: Harlow, UK, 1988; pp. 392-413.

134. Munns, R. Comparative physiology of salt and water stress. Plant Cell Environ. 2002, 25, 239-250. [CrossRef] [PubMed]

135. Xi, J.J.; Chen, H.Y.; Bai, W.P.; Yang, R.C.; Yang, P.Z.; Chen, R.J.; Hu, T.M.; Wang, S.M. Sodium-related adaptations to drought: New insights from the xerophyte plant Zygophyllum xanthoxylum. Front. Plant Sci. 2018, 9, 1678. [CrossRef]

136. Carter, C.T.; Grieve, C.M.; Poss, J.A. Salinity effects on emergence, survival, and ion accumulation of Limonium perezii. J. Plant. Nutr. 2005, 28, 1243-1257. [CrossRef]

137. Greenway, H.; Munns, R. Mechanisms of salt tolerance in non-halophytes. Annu. Rev. Plant Physiol. 1980, 31, 149-190. [CrossRef]

138. Gil, R.; Bautista, I.; Boscaiu, M.; Lidón, A.; Wankhade, S.; Sánchez, H.; Llinares, J.; Vicente, O. Responses of five Mediterranean halophytes to seasonal changes in environmental conditions. AoB Plants 2014, 6, plu049. [CrossRef] [PubMed]

139. Percey, W.J.; Shabala, L.; Wu, Q.; Su, N.; Breadmore, M.C.; Guijt, R.M.; Bose, J.; Shabala, S. Potassium retention in leaf mesophyll as an element of salinity tissue tolerance in halophytes. Plant Physiol. Biochem. 2016, 109, 346-354. [CrossRef] [PubMed]

140. Assaha, D.; Ueda, A.; Saneoka, H.; Al-Yahyai, R.; Yaish, M.W. The role of $\mathrm{Na}^{+}$and $\mathrm{K}^{+}$transporters in salt stress adaptation in glycophytes. Front. Physiol. 2017, 8, 509. [CrossRef] [PubMed]

141. Ejaz, S.; Fahad, S.; Anjum, M.A.; Nawaz, A.; Naz, S.; Hussain, S.; Ahmad, S. Role of osmolytes in the mechanisms of antioxidant defense of plants. Sustain. Agric. Rev. 2020, 39. [CrossRef]

142. Tipirdamaz, R.; Gagneul, D.; Duhazé, C.; Aïnouche, A.; Monnier, C.; Özkum, D.; Larher, F. Clustering of halophytes from an inland salt marsh in Turkey according to their ability to accumulate sodium and nitrogenous osmolytes. Environ. Exp. Bot. 2006, 57, 139-153. [CrossRef]

143. Gagneul, D.; Aïnouche, A.; Duhazé, C.; Lugan, R.; Larher, F.R.; Bouchereau, A. A reassessment of the function of the so-called compatible solutes in the halophytic Plumbaginaceae Limonium latifolium. Plant Physiol. 2007, 144, 1598-1611. [CrossRef]

144. Al Hassan, M.; Pacurar, A.; López-Gresa, M.P.; Donat-Torres, M.P.; Llinares, J.V.; Boscaiu, M.; Vicente, O. Effects of salt stress on three ecologically distinct Plantago species. PLoS ONE 2016, 11, e0160236. [CrossRef]

145. Al Hassan, M.; Chaura, J.; Donat-Torres, M.; Boscaiu, M.; Vicente, O. Antioxidant responses under salinity and drought in three closely related wild monocots with different ecological optima. AoB Plants 2017, 9, plx009. [CrossRef]

146. Rhodes, D.; Nadolska-Orczyk, A.; Rich, P. Salinity, osmolytes and compatible solutes. In Salinity: Environment-Plants-Molecules; Läuchli, A., Lüttge, U., Eds.; Springer: Dordrecht, The Netherlands, 2002. [CrossRef]

147. Youssef, A.M.; Hassanein, R.A.; Hassanein, A.A.; Morsy, A.A. Changes in quaternary ammonium compounds, proline and protein profiles of certain halophytic plants under different habitat conditions. Pak. J. Biol. Sci. 2003, 6, 867-882. [CrossRef]

148. Yasseen, B.T.; Abu-Al-Basal, M.A. Ecophysiology of Limonium axillare and Avicennia marina from the coastline of Arabian Gulf-Qatar. Coast Conserv. 2008, 12, 35-42. [CrossRef]

149. Furtana, G.B.; Dumani, H.; Tipirdamaz, R. Seasonal changes of inorganic and organic osmolyte content in three endemic Limonium species of Lake Tuz (Turkey). Turk. J. Bot. 2013, 37, 455-463. [CrossRef]

150. Hanson, A.D.; Rathinasabapathi, B.; Chamberlin, B.; Gage, D.A. Comparative physiological evidence that beta-alanine betaine and choline-O-sulfate act as compatible osmolytes in halophytic Limonium species. Plant Physiol. 1991, 97, 1199-1205. [CrossRef]

151. Hanson, A.D.; Rathinasabapathi, B.; Rivoal, J.; Burnet, M.; Dillon, M.O.; Gage, D.A. Osmoprotective compounds in the Plumbaginaceae: A natural experiment in metabolic engineering of stress tolerance. Proc. Natl. Acad. Sci. USA 1994, 91, 306-310. [CrossRef]

152. Liu, X.; Duan, D.; Li, W.; Tadano, T.; Khan, A.M. A comparative study on responses of growth and solute composition in halophytes Suaeda Salsa and Limonium Bicolor to salinity. In Ecophysiology of High Salinity Tolerant Plant. Tasks for Vegetation Science; Springer: Dordrecht, The Netherlands, 2006; Volume 40. [CrossRef] 
153. Bouchereau, A.; Duhazé, C.; Martin-Tanguy, J.; Guégan, J.P.; Larher, F. Improved analytical methods for determination of nitrogenous stress metabolites occurring in Limonium species. J. Chromatogr. 1999, 836, 209-221. [CrossRef]

154. Murakeözy, É.P.; Smirnoff, N.; Nagy, Z.; Tuba, Z. Seasonal accumulation pattern of pinitol and other carbohydrates in Limonium gmelinii subsp. Hungarica. J. Plant Physiol. 2002, 159, 485-490.

155. Murakeözy, É.P.; Nagy, Z.; Duhazé, C.; Bouchereau, A.; Tuba, Z. Seasonal changes in the levels of compatible osmolytes in three halophytic species of inland saline vegetation in Hungary. J. Plant Physiol. 2003, 160, 395-401. [CrossRef] [PubMed]

156. Liu, X.; Grieve, C. Accumulation of chiro-inositol and other non-structural carbohydrates in Limonium species in response to saline irrigation waters. J. Am. Soc. Hortic. Sci. 2009, 134, 329-336. [CrossRef]

157. Akat, Ö.; Çakar, H. Yield response of Limonium sinuatum cultivars under salinity stress. J. Environ. Biol. 2020, 41, 302-309. [CrossRef]

158. Saibi, W.; Brini, F. Proline, a peculiar amino acid with astucious functions in development and salt tolerance process in plants. J. Food Nutr. Metab. 2020, 3, 1-8. [CrossRef]

159. Rhodes, D.; Hanson, A.D. Quaternary ammonium and tertiary sulfonium compounds in higher plants. Annu. Rev. Plant Physiol. Plant Mol. Biol. 1993, 44, 357-384. [CrossRef]

160. Rivoal, J.; Hanson, A. Choline-O-sulfate biosynthesis in plants (Identification and partial characterisation of a salinity-inducible choline sulfotransferase from species of Limonium (Plumbaginaceae). Plant Physiol. 1994, 106, 1187-1193. [CrossRef] [PubMed]

161. Del Rio, D.; Stewart, A.J.; Pellegrini, N. A review of recent studies on malondialdehyde as toxic molecule and biological marker of oxidative stress. Nutr. Metab. Cardiovasc. Dis. 2005, 15, 316-328. [CrossRef]

162. Černý, M.; Habánová, H.; Berka, M.; Luklová, M.; Brzobohatý, B. Hydrogen peroxide: Its role in plant biology and crosstalk with signalling networks. Int. J. Mol. Sci. 2018, 19, 2812. [CrossRef] [PubMed]

163. Barsukova, M.E.; Veselova, I.A.; Shekhovtsova, T.N. Main methods and approaches to the determination of markers of oxidative stress-Organic peroxide compounds and hydrogen peroxide. J. Anal. Chem. 2019, 74, 425-436. [CrossRef]

164. Alscher, R.G.; Erturk, N.; Heath, L.S. Role of superoxide dismutases (SODs) in controlling oxidative stress in plants. J. Exp. Bot. 2002, 53, 1331-1341. [CrossRef] [PubMed]

165. Caverzan, A.; Casassola, A.; Brammer, S.P. Antioxidant responses of wheat plants under stress. Genet. Mol. Biol. 2016, 39, 1-6. [CrossRef] [PubMed]

166. Gunes, A.; Pilbeam, D.J.; Inal, A.; Bagci, E.G.; Coban, S. Influence of silicon on antioxidant mechanisms and lipid peroxidation in chickpea (Cicer arietinum L.) cultivars under drought stress. J. Plant Interact. 2007, 2, 105-113. [CrossRef]

167. Rao, A.C.; Reddy, A.R. Glutathione reductase: A putative redox regulatory system in plant cells. In Sulfur Assimilation and Abiotic Stress in Plants; Khan, N.A., Singh, S., Umar, S., Eds.; Springer: Berlin/Heidelberg, Germany, 2008; pp. 111-147.

168. Fini, A.; Brunetti, C.; di Ferdinando, M.; Ferrini, F.; Tattini, M. Stress-induced flavonoid biosynthesis and th3 antioxidant machinery of plants. Plant Signal. Behav. 2011, 6, 709-711. [CrossRef]

169. Davies, K.M.; Albert, N.W.; Zhou, Y.; Schwinn, K.E. Functions of flavonoid and betalain pigments in abiotic stress tolerance in plants. In Annual Plant Reviews Online; Roberts, J.A., Ed.; John Wiley \& Sons, Ltd.: Hoboken, NJ, USA, 2018. [CrossRef]

170. Jithesh, M.N.; Prashanth, S.R.; Sivaprakash, K.R.; Parida, A.K. Antioxidative response mechanisms in halophytes: Their role in stress defence. J. Gen. 2006, 85, 237-254. [CrossRef]

171. Ozgur, R.; Uzilday, B.; Sekmen, A.H.; Turkan, I. Reactive oxygen species regulation and antioxidant defence in halophytes. Funct. Plant Biol. 2013, 40, 832-847. [CrossRef] [PubMed]

172. Bose, J.; Rodrigo-Moreno, A.; Shabala, S. ROS homeostasis in halophytes in the context of salinity stress tolerance. J. Exp. Bot. 2014, 65, 1241-1257. [CrossRef] [PubMed]

173. Souid, A.; Bellani, L.; Magné, C.; Zorrig, W.; Smaoui, A.; Abdelly, C.; Longo, V.; Hamed, B.K. Physiological and antioxidant responses of the sabkha biotope halophyte Limonium delicatulum to seasonal changes in environmental conditions. Plant Physiol. Biochem. 2018, 123, 180-191. [CrossRef] [PubMed] 